\title{
21. PRIMARY COMPOSITION, ALTERATION, AND ORIGIN OF CRETACEOUS VOLCANICLASTIC ROCKS, EAST MARIANA BASIN (SITE 585, LEG 89) ${ }^{1}$
}

\author{
L. G. Viereck, M. Simon, and H.-U. Schmincke, Institut für Mineralogie, Ruhr-Universität Bochum²
}

\begin{abstract}
An upper Aptian to middle Albian series of volcaniclastic rocks more than $300 \mathrm{~m}$ thick was drilled at Site 585 in the East Mariana Basin. On the basis of textural and compositional (bulk-rock chemistry, primary and secondary mineral phases) evidence, the volcaniclastic unit is subdivided into a lower (below $830 \mathrm{~m}$ sub-bottom) and an upper (about 670 $760 \mathrm{~m}$ ) sequence; the boundary in the interval between is uncertain owing to lack of samples.

The rocks are dominantly former vitric basaltic tuffs and minor lapillistones with lesser amounts of crystals and basaltic lithic clasts. They are mixed with shallow-water carbonate debris (ooids, skeletal debris), and were transported by mass flows to their site of deposition.

The lower sequence is mostly plagioclase- and olivine-phyric with lesser amounts of Ti-poor clinopyroxene. Mineralogical and bulk-rock chemical data indicate a tholeiitic composition slightly more enriched than N-MORB (normal mid-ocean ridge basalt). Transport was by debris flows from shallow-water sites, as indicated by admixed ooids. Volcanogenic particles are chiefly moderately vesicular to nonvesicular blocky shards (former sideromelane) and less angular tachylite with quench plagioclase and pyroxene, indicating generation of volcanic clasts predominantly by spalling and breakage of submarine pillow and/or sheet-flow lavas.

The upper sequence is mainly clinopyroxene- and olivine-phyric with minor plagioclase. The more Ti-rich clinopyroxene and the bulk-rock analyses show that the moderately alkali basaltic composition throughout is more mafic than the basal tholeiitic sequence. Transport was by turbidity currents. Rounded epiclasts of crystalline basalts are more common than in the lower sequence, and, together with the occurrence of oxidized olivine pseudomorphs and vesicular tachylite, are taken as evidence of derivation from eroded subaerially exposed volcanics. Former sideromelane shards are more vesicular than in the lower sequence; vesicularity exceeds $60 \mathrm{vol} . \%$ in some clasts. The dominant clastic process is interpreted to be by shallow-water explosive eruptions.

All rocks have undergone low-temperature alteration; the dominant secondary phases are "palagonite," chlorite/ smectite mixed minerals, analcite, and chabazite. Smectite, chlorite, and natrolite occur in minor amounts. Phillipsite is recognized as an early alteration product, now replaced by other zeolites. During alteration, the rocks have lost up to $50 \%$ of their $\mathrm{Ca}$, compared with a fresh shard and fresh glass inclusions in primary minerals, but have gained much less $\mathrm{K}, \mathrm{Rb}$, and $\mathrm{Ba}$ than expected, indicating rapid deposition prior to significant seafloor weathering.
\end{abstract}

\section{INTRODUCTION}

Most submarine volcaniclastic rocks are made up of (formerly) glassy, vesicular clasts resulting from shallowwater explosive eruptions on seamounts or island arcs, but the volume of volcaniclastic material is generally small (a few tens of meters in the cores), except in drill holes proximal to highly active areas such as island arcs (e.g., Legs 59, 60), where epiclastic material dominates.

Volcaniclastic rocks were drilled during Leg 89 at Site 585 in the East Mariana Basin $\left(13^{\circ} 29.00^{\prime} \mathrm{N}, 156^{\circ} 48.91^{\prime} \mathrm{E}\right.$; Fig. 1A), in $6109 \mathrm{~m}$ of water $70 \mathrm{~km}$ north of a major Cretaceous eruptive site, the Ita Maitai Guyot (Fig. 1B).

A total of $893 \mathrm{~m}$ was drilled at two holes: $763 \mathrm{~m}$ in Hole 585 and an additional $160 \mathrm{~m}$ in Hole 585A (Fig. 2). The upper $590 \mathrm{~m}$ of the sediments consists predominantly of nannofossil chalk and zeolitic claystone (Units I to V), with minor Upper Cretaceous to Eocene volcaniclastic material. These sediments are underlain by a $300-\mathrm{m}-$ thick section of volcaniclastic rocks (Unit VI) dated as late Aptian to middle Albian (about $110-100 \mathrm{Ma}$ ) on

\footnotetext{
${ }^{1}$ Moberly, R., Schlanger, S. O., et al., Init. Repts. DSDP, 89: Washington (U.S. Govt. Printing Office).

2 Address: Institute für Mineralogie, Ruhr Universität Bochum, Postfach 1021 48, D. 4630 Bochum 1, Federal Republic of Germany.
}

the basis of calcareous shallow-water debris (see Site 585 report, this volume).

Recovery rate in the volcaniclastic sediments was moderate to good in Hole 585 and good in $585 \mathrm{~A}$, averaging $70 \%$ for Cores 11 to 22 of Hole 585A.

We studied selected rocks throughout the volcaniclastic section (Unit VI) to contribute to the understanding of (1) Cretaceous midplate plateau-type volcanism, which produced widespread and thick volcaniclastic rocks; (2) the nature of the clastic processes (pyro-, hydro-, or epiclastic); (3) the site of eruptions (water depth and/or subaerial activity); (4) the tectonic environment of volcanic activity, or at least the primary compositions of the magmas, as inferred, with caution, from preserved phenocryst and bulk-rock compositions; and (5) the nature of the alteration processes that have affected and thoroughly transformed all rocks studied.

\section{ANALYTICAL METHODS}

Twenty-eight samples, representing about 18 sedimentary units, were studied in detail. Thin sections of all samples, were prepared and some were analyzed by X-ray diffraction (XRD) to identify zeolite species. Primary and secondary mineral phases, altered and fresh glass shards, and glass inclusions in phenocrysts were analyzed ( 400 analyses in 11 polished thin sections) using the wavelength-dispersive system of a CAMEBAX automated microprobe (Cameca). Correction of raw data was done using the program CORREX (CAMEBAX). A defocused beam current $(5 \times 5 \mu \mathrm{m})$ of $14 \mathrm{nA}$ at $15 \mathrm{kV}$ was used for analyses, ex- 
A

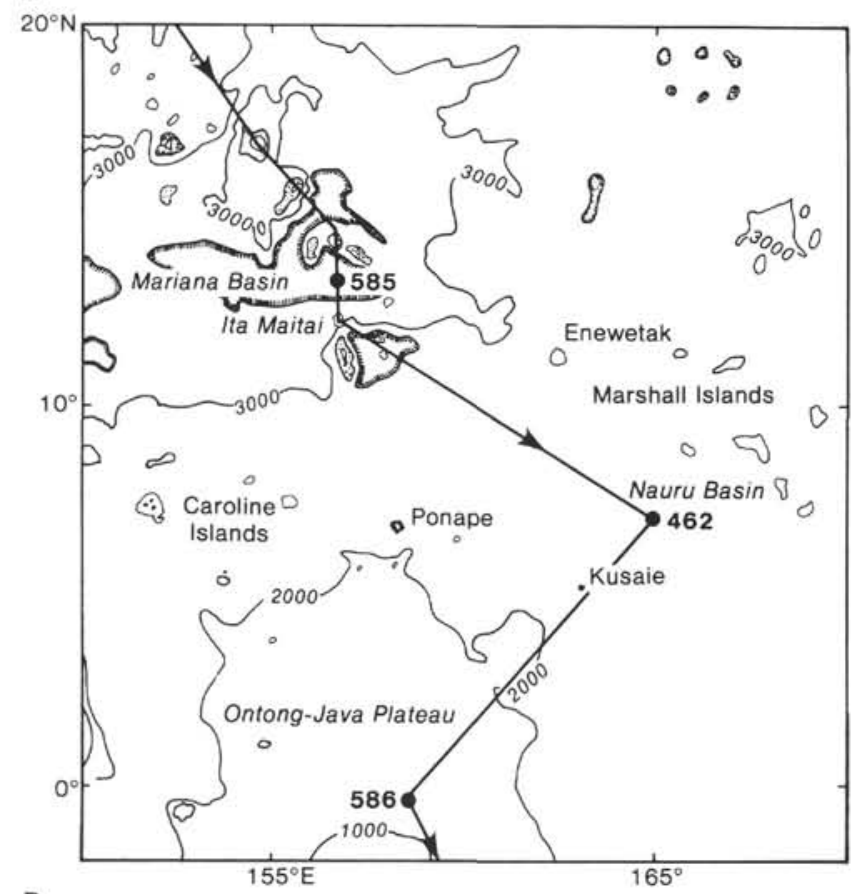

B

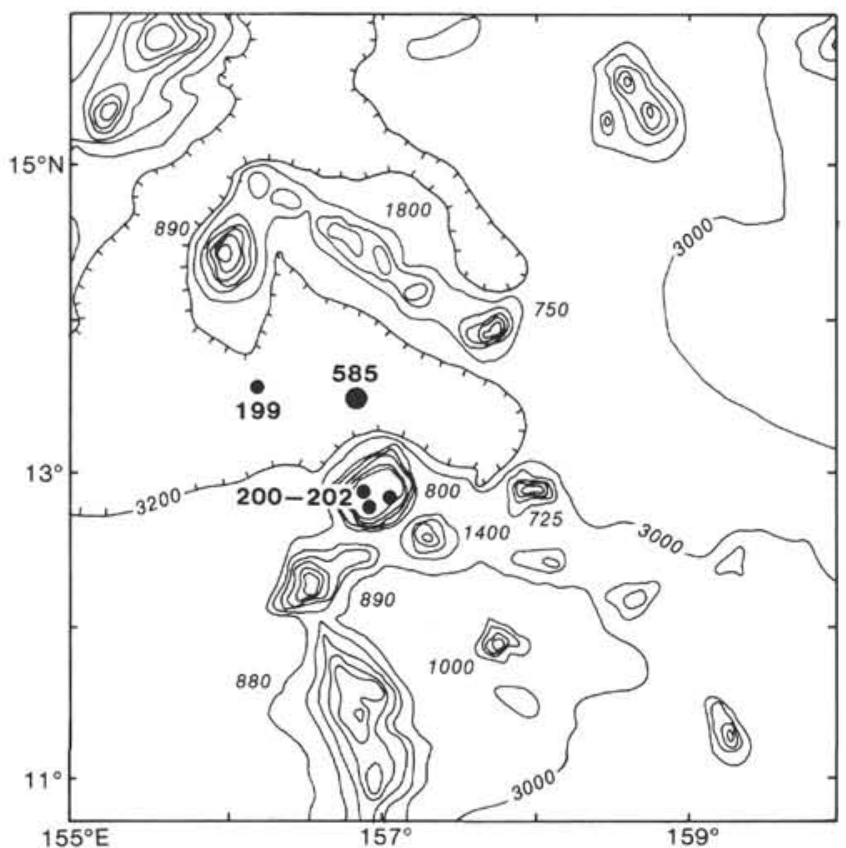

Figure 1. A. Location of DSDP Site 585 in the western Pacific. B. Detailed map of the East Mariana Basin. For comparison: DSDP Sites 199 and 200 to 202, drilled on Ita Maitai Guyot, about $70 \mathrm{~km}$ south of Site 585. (Contours in fathoms.)

cept for more sensitive phases like palagonitized glass and selected phyllosilicates (analyzed with $7 \mathrm{nA}$ and enlarged area scan of up to 20 $\times 20 \mu \mathrm{m})$. Ten whole-rock samples were analyzed by X-ray fluorescence (XRF) (Philips PW 1400) for 13 major and 11 trace elements. $\mathrm{FeO}, \mathrm{CO}_{2}$, and $\mathrm{H}_{2} \mathrm{O}$ were analyzed by classical standard techniques (methods described by Simon and Schmincke, 1984).

\section{PETROGRAPHY}

The sedimentary sequence was subdivided into six lithologic units by the shipboard party (Fig. 2). The upper five units, from the top to about $590 \mathrm{~m}$ sub-bottom, are middle Albian to Recent fine-grained nannofossil- and/ or radiolarian-bearing sediments. Below, volcaniclastic mass-flow deposits dominate (Unit VI). These can be subdivided into two major parts, which for simplicity we call the lower and upper sequences. Deposits of the lowermost part of the mass-flow sequence, below Core 16 of Hole $585 \mathrm{~A}(830 \mathrm{~m}$ to end of core at $893 \mathrm{~m})$ are extremely poorly sorted; grain sizes of particles range from boulder to silt, and are lithologically very heterogeneous. Large subrounded fragments of siltstone and claystone are mixed with shallow-water carbonate debris, limestone, and volcanic clasts within finer-grained (coarse sand to silt) volcaniclastic "matrix." These sediments are interpreted to be parts of one or more debris-flow deposits. They are overlain by about $250 \mathrm{~m}$ of volcaniclastic turbidity-current deposits, many showing typical Bouma cycles (upper sequence). The median grain size of most rocks studied is in the sand-size range. Thus, the rocks are dominantly vitric tuffs. Lapillistones are much less abundant, and contain a higher proportion of lithic components.

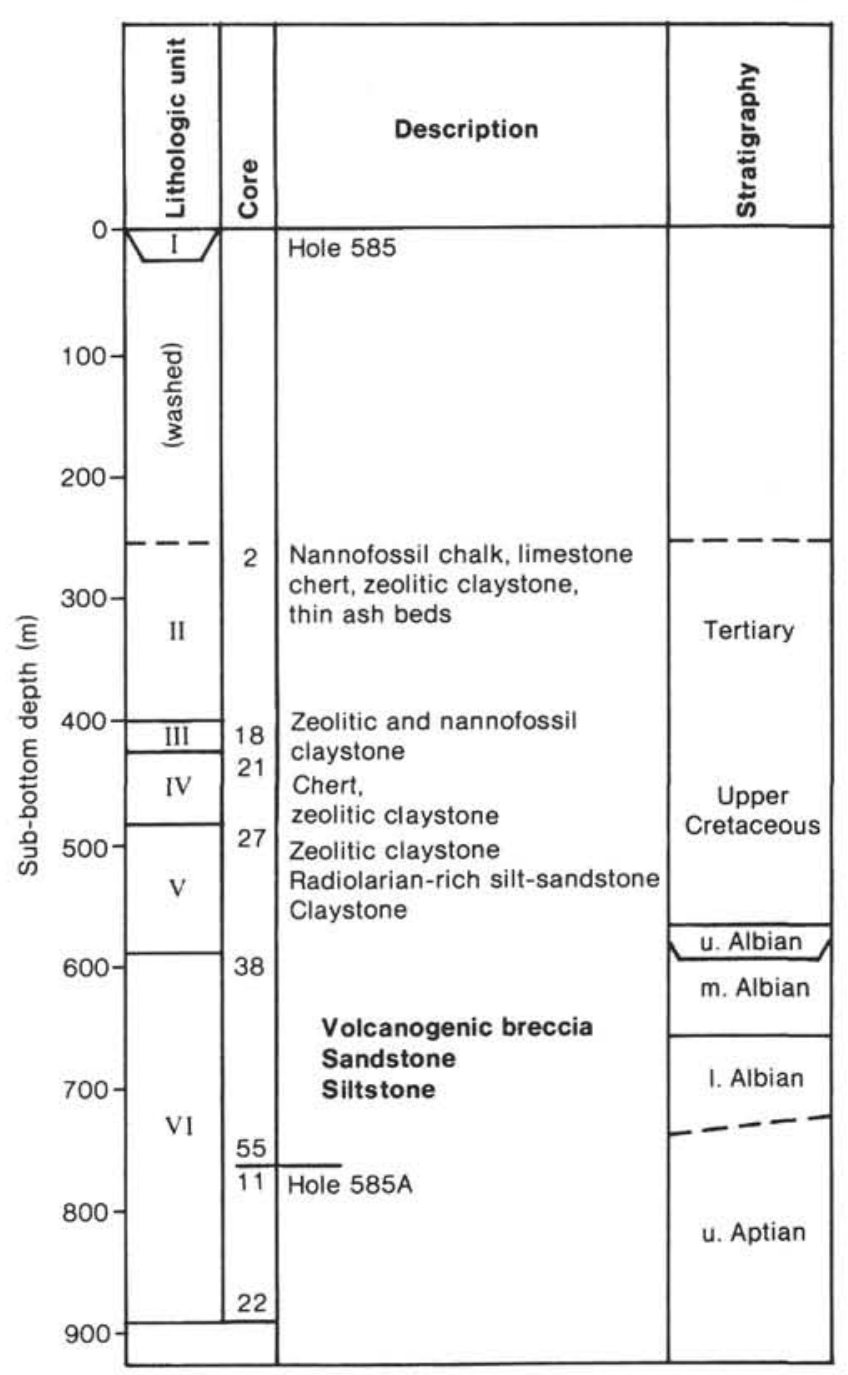

Figure 2. Simplified lithologic profile of Site 585. 


\section{PRIMARY COMPONENTS}

\section{Vitric Shards}

Altered vitric shards constitute the most abundant clast type in almost all samples. Despite severe alteration, shard types are still recognizable, and several primary shard types were distinguished:

1. Vesicle-free to vesicle-poor spalling shards are elongate and show straight to slightly curved outlines.

2. Bubble-wall shards are distinguished from the first type by their concave boundaries, but this distinction is not always conclusive.

Both shard types occur in grain sizes of less than $50 \mu \mathrm{m}$, to about $350 \mu \mathrm{m}$, and rarely reach more than $500 \mu \mathrm{m}$ in length. These two types may be grouped together as "simple shards," in contrast to "compound shards," which are commonly larger (Schmincke et al., 1982).

Two main types of compound shards are distinguished (Plate 1):

3. Blocky shards are vesicle-free to vesicle-poor (less than 20 vol.\%), slightly rounded to well rounded, and equant. Their vesicles are mostly less than $50 \mu \mathrm{m}$ in diameter, rarely exceeding $500 \mu \mathrm{m}$, and are commonly perfectly round. Shard outlines are not modified by walls of broken vesicles; this is one of the main criteria for distinguishing them from scoria.

4. Scoria shards are more vesicular $(>20$ vol. $\%$, some exceeding $50 \mathrm{vol. \%}$ ). Vesicles, up to $1000 \mu \mathrm{m}$ in diameter, greatly vary in shape and size. Most probably, all shards were of basaltic composition, because we found no independent evidence that any vitric clast was of more differentiated composition.

\section{Lithic Volcanic Clasts}

Lithic volcanic clasts, ranging from trace amounts to $50 \mathrm{vol} . \%$ (Table 1), with grain size from $<100 \mu \mathrm{m}$ to $\gg 5 \mathrm{~mm}$, are of two main types, tachylite and crystalline basalt; a few lithic volcanic clasts are of intermediate crystallinity.

\section{Tachylite}

We distinguished three main types of tachylite:

1. Poorly vesicular, angular to subrounded variolitic tachylite may grade into formerly vitric basalt (sideromelane). This tachylite is interpreted to represent fragments of rinds of pillows or sheet flows which erupted under water and were subsequently eroded. This type of tachylite occurs mostly in the lower sequence (Hole 585A, Cores 16-19), and is rare in the upper (Cores 55-42 of Hole 585).

2. A second type of tachylite contains from 5 to 25 vol.\% vesicles and has a dense opaque texture without feathery quench pyroxene and/or plagioclase. Vesicle diameters range from 50 to over $500 \mu \mathrm{m}$. Walls between bubbles are much thicker than in formerly glassy scoria shards. At least some of these vesicular tachylite clasts may have formed by explosive eruptions on land.

3. A third type of tachylite is similar to type 2, except that it is nonvesicular and has irregular shapes. It could have formed by erosion of aa-type basalt or possibly from granulating lava flowing from land into the sea. Tachylite $\mathrm{b}$ and $\mathrm{c}$ dominate in the upper sequence of Unit VI (Hole 585, Cores 46-55).

Phenocryst types, sizes, and abundances in the tachylite appear to be identical to those in the formerly glassy shards, indicating that both were derived from the same type of lava.

\section{Crystalline Basalt}

Crystalline basalt, with intergranular to intersertal texture, consists mainly of plagioclase, clinopyroxene, titanomagnetite, ilmenite, and olivine. Grain sizes of minerals vary widely, and include very coarse-grained doleritic basalt. Rare plagioclase-rich clasts with trachytic texture are interpreted as hawaiitic to mugearitic basalts. Characteristically, most crystalline basalt clasts are subrounded, but include both angular and rounded fragments. Olivine phenocrysts in several clasts show evidence of former high-temperature oxidation. We interpret all crystalline clasts to be formed by erosion of lava flows on land or in the land/water transition zone. Crystalline basalts generally make up less than $10 \mathrm{vol} . \%$, except for some mixed sediments in the interval of Cores 49 to 55 from Hole 585, where they make up as much as 25 vol.\% (Table 1).

\section{Tuffaceous Silts and Clays}

Ellipsoidal to ovoid-shaped "lumps" of smectitic siltstone to claystone, some containing indistinct radiolarians, are generally markedly larger than the median grain size of all accompanying clasts (Table 1). Most of these clasts, which may reach several millimeters in length, contain abundant vitric shards, but they are too finegrained for more precise petrographic analysis. Where the morphology of vitric components can be identified, they are exclusively spalling shards; hyaloclastite fragments sensu stricto (Fisher and Schmincke, 1984) are rare.

\section{Crystals}

Crystals are the least common of the major components; they range between 1 and $3 \mathrm{vol} . \%$, but constitute up to $10 \mathrm{vol} . \%$ of samples from Cores 49 to 55 of Hole 585 (Table 1). They occur as euhedral to subhedral phenocrysts or quenched microphenocrysts in palagonitized shards, or as broken subhedral to anhedral single crystals. Phenocrysts are generally less than $1 \mathrm{~mm}$ in size, but exceed maximum diameters of $2 \mathrm{~mm}$ in Cores 49 to 55 of Hole 585. Plagioclase, clinopyroxene, and olivine make up more than $98 \mathrm{vol} . \%$ of the bulk crystal content. Olivine and/or plagioclase dominate over pyroxene in the lower sequence (Hole 585A, Cores 17-19; Fig. 3). Titaniferous magnesiochromites, ilmenite, and titanomagnetites occur in minor or trace amounts, and are least abundant in the lower sequence (Hole 585A, Cores 16-19). Amphibole and biotite are accidental single crystals in a few cores of the upper sequence in Unit VI (Hole 585). 
Table 1. Petrographic data of studied volcanogenic sediments of Unit VI, Site 585.

\begin{tabular}{|c|c|c|c|c|c|c|c|c|c|c|c|c|}
\hline \multirow[b]{2}{*}{$\begin{array}{c}\text { Sample } \\
\text { (interval in } \mathrm{cm} \text { ) }\end{array}$} & \multicolumn{2}{|c|}{ Estimated grain size } & \multicolumn{7}{|c|}{ Particles (est. vol.\%) } & \multicolumn{3}{|c|}{$\begin{array}{l}\text { "Groundmass" } \\
\text { (est. vol.\%) }\end{array}$} \\
\hline & $\begin{array}{l}\text { Median }^{\mathrm{a}} \\
(\mu \mathrm{m})\end{array}$ & $\underset{(\mathrm{mm})}{\text { Maximum }}$ & Vitric & Tachylite & & $\begin{array}{c}\text { Crystalline } \\
\text { basalt }\end{array}$ & Crystal & Tuff $^{b}$ & Carbonate $^{c}$ & $\frac{\text { "Matrix" }}{\text { "S }}$ & & Cement \\
\hline $585-42-3,30-34$ & 100 & 0.20 & $<60$ & & $\operatorname{tr}^{\mathrm{i}}$ & & 5 & & $5-10$ & ? & & $>25$ \\
\hline $585-43-2,140-142$ & 150 & 0.35 & $<60$ & & $\mathrm{tr}$ & & 5 & & 5 & ? & & $>25$ \\
\hline $585-46-3,142-146$ & 200 & $>8$ & $45 ?$ & & 2 & & 1 & 10 & $<1$ & 35 & & 5 \\
\hline $585-47-1,102-105$ & $200+1500$ & $>4$ & 30 & & 1 & & $1-2$ & 50 & $1^{f}$ & 5 & & 15 \\
\hline $585-47-2,83-85$ & 300 & 1.4 & 50 & & $<10$ & & $1-2$ & & $1-2^{f}$ & 5 & & 30 \\
\hline $585-48-1,32-36$ & $700-1200$ & 4 & 55 & 10 & & 5 & $2-3$ & & $2-4^{f}$ & 20 & & 5 \\
\hline $585-48-2,44-47$ & 40 & 0.3 & 55 & 2 & & 2 & 3 & & & $?$ & & 40 \\
\hline $585-49-2,46-48$ & $80-150+2000$ & 4 & 50 & 2 & & 2 & 3 & $5-10$ & $\operatorname{tr}$ & ? & & 40 \\
\hline $585-49-2,90-94$ & 250 & 3 & 60 & 2 & & 2 & 1 & & & & $40^{i}$ & \\
\hline $585-49-2,108-110$ & 400 & $>4$ & 50 & 2 & & $i$ & 3 & & tr & & 40 & \\
\hline $585-49-2,115-117$ & 100 & 0.6 & $10 ?$ & 30 & & 20 & 10 & & 1 & & 45 & \\
\hline $585-50-4,35-39$ & 150 & 0.5 & 10 & 20 & & 15 & 10 & & 15 & 5 & & 25 \\
\hline $585-54-1,57-59$ & 800 & 2 & 20 & 25 & & 15 & 10 & & tr & 5 & & 25 \\
\hline $585-54-2,73-75$ & $1400-2000$ & $>5$ & 10 & 25 & & 25 & 2 & & $<1$ & & 30 & \\
\hline $585-54-2,144-147$ & 400 & 1.2 & 40 & 10 & & 15 & 10 & & & & 40 & \\
\hline $585-55-2,78-82$ & 250 & $>2$ & 45 & 10 & & 15 & 8 & tr & $<1$ & - & & 20 \\
\hline $585-55-3,122-127$ & 500 & 2 & 40 & 15 & & 15 & 10 & tr & $<1$ & 5 & & 15 \\
\hline $585 \mathrm{~A}-16-3,37-39$ & $100+700$ & $>5$ & 25 & tr & & $?$ & 1 & 50 & $1-2$ & - & & 25 \\
\hline $585 \mathrm{~A}-16-4,79-81$ & $160+800$ & $>6$ & 25 & tr & & ? & 1 & 50 & $1-2$ & - & & 25 \\
\hline $585 \mathrm{~A}-16, \mathrm{CC}$ & 200 & 1 & 50 & 5 & & 5 & 3 & tr & $10^{\mathrm{f}}$ & - & & 25 \\
\hline $585 \mathrm{~A}-17-1,11-14$ & 250 & 1.8 & 50 & 6 & & 9 & 1 & & $10^{\mathrm{f}}$ & - & & 25 \\
\hline $585 \mathrm{~A}-17-3,183-141$ & 350 & 1.5 & $40-45$ & 5 & & 5 & 2 & & $12^{\mathrm{f}}$ & ? & & 30 \\
\hline $585 \mathrm{~A}-18-2,72-75$ & 500 & 2 & 50 & 8 & & 1 & 5 & & $10^{f}$ & 5 & & 25 \\
\hline $585 \mathrm{~A}-18-6,90-92$ & 700 & $>3$ & $40-45$ & 8 & & 7 & 2 & & $10^{\mathrm{f}}$ & 10 & & 20 \\
\hline $585 \mathrm{~A}-19-1,42-45$ & 1000 & $>3$ & 40 & $10^{\circ}-(x)-10$ & & 3 & $2-3$ & & $8-10^{f}$ & $<30$ & & 10 \\
\hline $585 \mathrm{~A}-19-2,89-95$ & & $>10$ & 30 & 2 & & $1-2$ & $2-3$ & 10 & $8-10^{f}$ & 15 & & 30 \\
\hline
\end{tabular}

Note: Blank spaces indicate absence; - indicates uncertainty.

a Two values given for shards and tuff or lithic clasts if markedly different.

b Includes radiolarian-bearing siltstones.

c Includes ooids, peloids, shallow-water biogenic and limestone fragments (f)

d Nos. in ( ) give exceptional maximum values. " 0 " = no vesicles visible due to alteration or extremely small size of shards.

e sme = smectite; ill = illite; zeo = zeolite; $\mathrm{chl}=$ chlorite; $\mathrm{pal}=$ palagonite; leux = leucoxene; $\mathrm{Cc}=$ calcite; oxid = various cryptocrystalline opaque phases; $($ )

$=$ uncertain.

f See c, above.

$\mathrm{g}$ Including natrolite.

h Including apophyllite, calcite, Ca-sulfate.

i Offset entries are used where it was not possible to distinguish between two alternatives.

\section{Olivine}

Olivine, the dominant mineral phase in the lower sequence, is always completely replaced (Plate 2, Figs. 1, 2 ). It is recognized by its euhedral to subhedral morphology and the common occurrence of chromite inclusions. Olivine pseudomorphs in samples from Cores 54 and 55 , Hole 585 , show red high-temperature oxidation along fractures and mineral faces, possibly suggesting subaerial origin of these clasts.

\section{Plagioclase}

Plagioclase is most common in the lower $60 \mathrm{~m}(<2$ vol.\%), and is rare in the upper sequence. It occurs as subhedral phenocrysts in shards and tachylitic and crystalline basaltic fragments, and as single crystals, mostly broken. Plagioclase, more than $1 \mathrm{~mm}$ in length, is restricted to samples from the lower debris-flow section. Quenched plagioclase microphenocrysts occur in shards (most commonly 50-150 $\mu \mathrm{m}$ in length) and tachylitic clasts, and in matrix of crystalline basaltic clasts (50$300 \mu \mathrm{m}$ ).

All plagioclase microphenocrysts are replaced by chlorite/smectite mixed-mineral aggregates, K-feldspar, albite, or analcite. Larger phenocrysts, however, are less affected by alteration. Plagioclase composition ranges from $\mathrm{An}_{60}$ to $\mathrm{An}_{72}$ throughout Unit VI (Table 2); zoning is minor. Single crystals in Cores 18 and 19, Hole 585A, span a wider compositional range and are either more calcic $\left(\mathrm{An}_{82}\right)$ or more sodic $\left(\mathrm{An}_{50}\right.$ to $\left.\mathrm{An}_{60}\right)$ than plagioclase in shards.

\section{Pyroxene}

Pyroxene is the most common and least altered primary mineral phase in the volcaniclastic rocks of Unit VI. It occurs as prismatic macro- and microphenocrysts and anhedral splinters of single crystals. In the lower sequence, pyroxene is almost absent in shards, but may occur as small crystals in the matrix. Pyroxene varies from 0.5 to $1.0 \mathrm{~mm}$ in length, depending on the median grain size of the sediment. Most pyroxenes are colorless, but some single zoned crystals are pink to light brown toward the rim in samples from Cores 54 and 55, Hole 585. Pyroxene compositions, determined by microprobe analyses of about 100 points in rocks from 10 sedimentary units (Table 3), can be divided into two groups which correlate well with the stratigraphic position of the sample (Fig. 3, 4). Augite-subcalcic augite-pigeonite associations are characteristic of Cores 18 and 19 (Hole 585A), whereas rocks from the upper sequence (Hole 585) contain diopsides and Ca-rich augites (salites). Pyroxenes of both associations show 0.3 to $1.0 \mathrm{wt} . \%$, rarely $1.3 \mathrm{wt} . \%$, of $\mathrm{Cr}_{2} \mathrm{O}_{3}$, indicating a primitive character for both (Schweitzer et al., 1979). The Ca- and Ti-poor pyroxenes are 
Table 1 (continued).

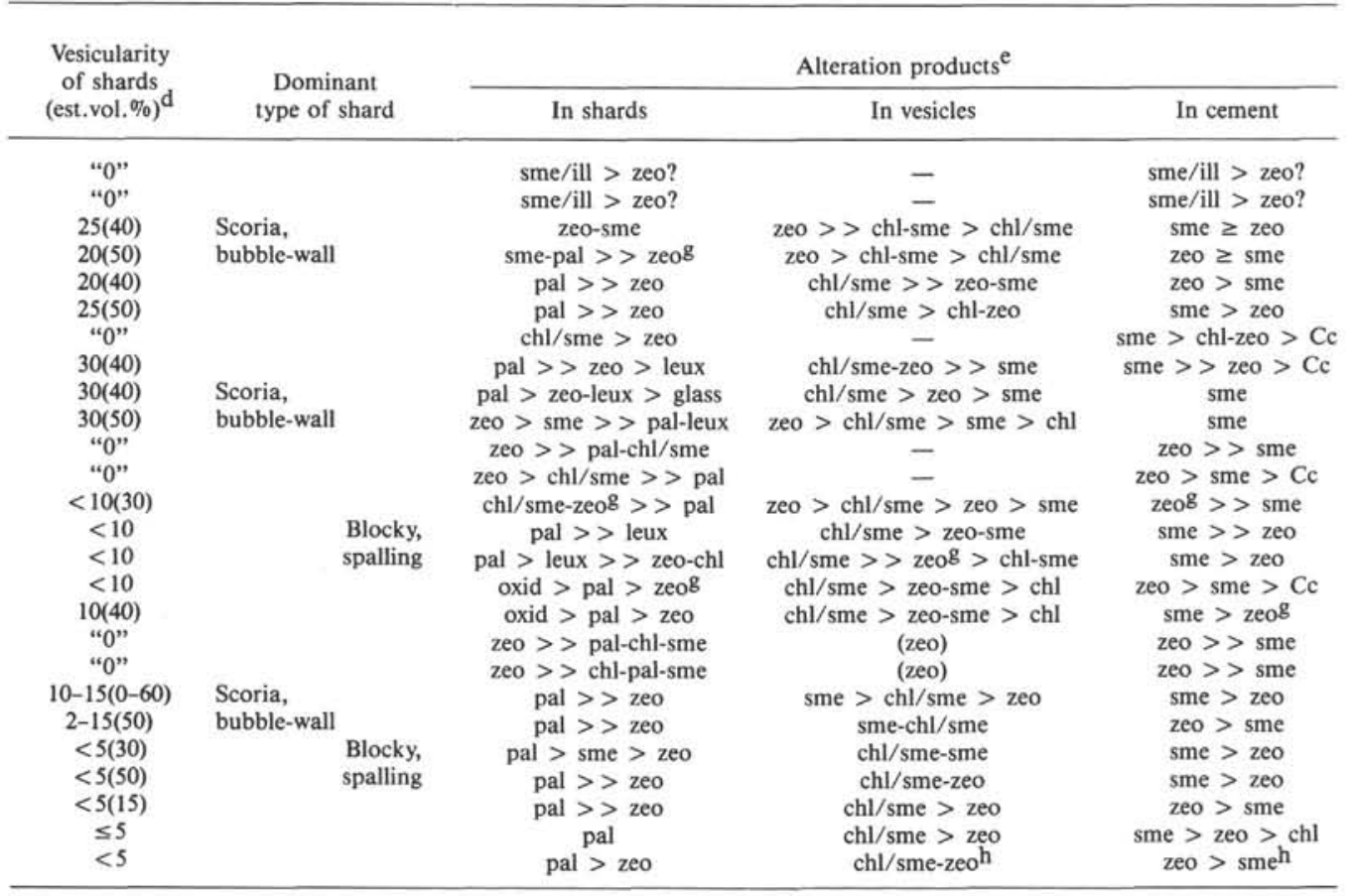

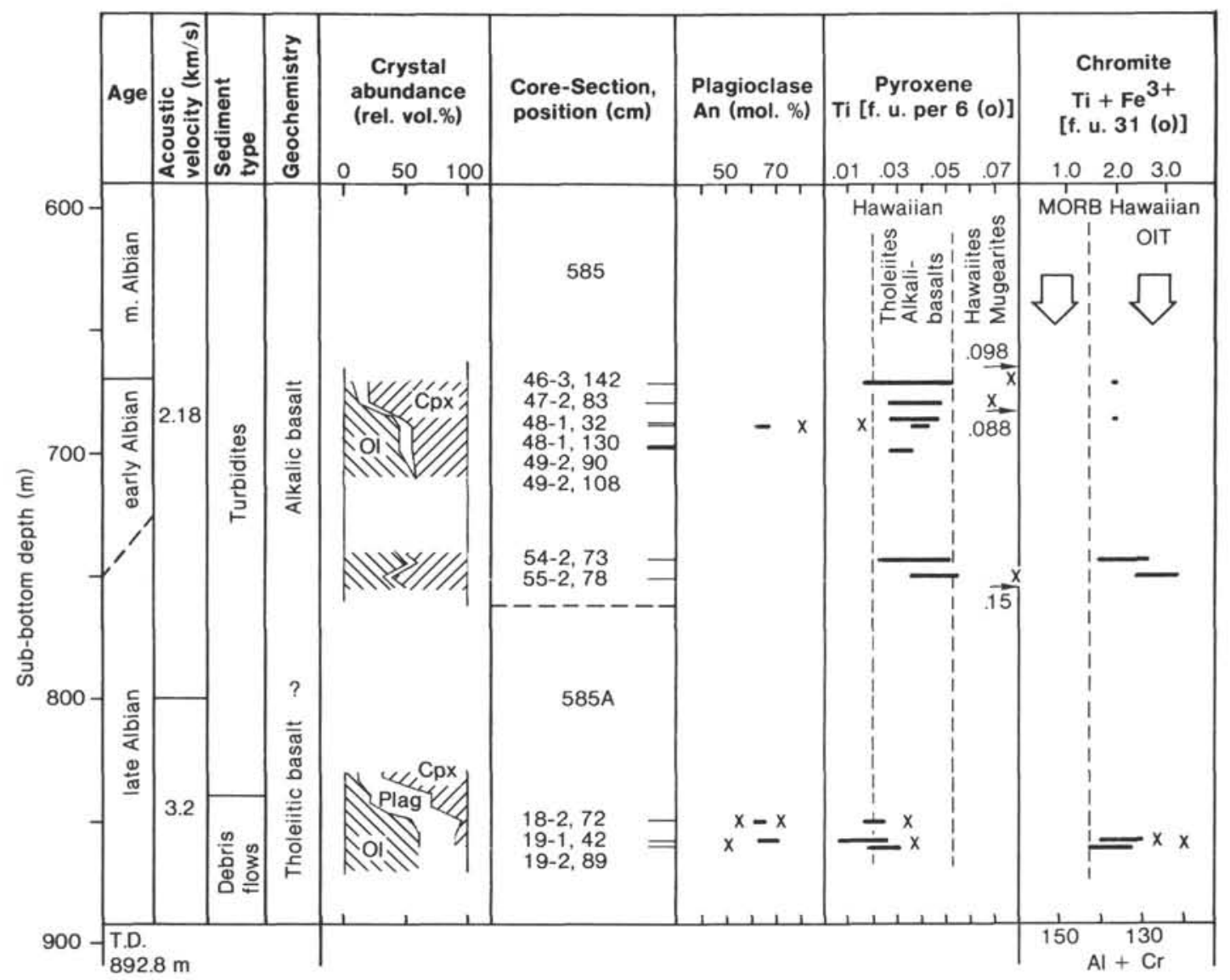

Figure 3. Stratigraphic distribution of analyzed primary volcanic minerals in Unit VI, Site 585. Note different Ti contents in pyroxenes but identical chromite compositions in samples from Holes 585 and $585 \mathrm{~A}$. Crosses indicate analyses of single crystals if different from compositional variation of crystals in shards (black horizontal bars). 
Table 2. Microprobe analyses (wt. \%) of selected primary minerals: plagioclase (1-3), amphibole (4), mica (5), Ti-magnesiochromite (6-9), and Ti-magnetite (10).

\begin{tabular}{|c|c|c|c|c|c|c|c|c|c|c|}
\hline & 1 & 2 & 3 & 4 & 5 & 6 & 7 & 8 & 9 & 10 \\
\hline $\mathrm{iO}_{2}$ & 47.72 & 52.10 & 53.56 & 40.09 & 36.17 & - & 0.01 & - & - & - \\
\hline $\mathrm{TiO}_{2}$ & 0.02 & 0.12 & 0.08 & 5.77 & 6.73 & 1.60 & 2.08 & 2.38 & 6.83 & 2.35 \\
\hline $\mathrm{Al}_{2} \mathrm{O}_{3}$ & 31.72 & 30.21 & 28.70 & 13.65 & 13.29 & 23.08 & 20.72 & 19.29 & 15.90 & 0.67 \\
\hline $\mathrm{Fe}_{2} \mathrm{O}_{3}$ & 0.63 & 0.45 & 0.61 & - & - & 7.00 & 8.56 & 10.71 & 10.60 & 53.22 \\
\hline $\mathrm{FeO}$ & - & - & - & 13.46 & 20.79 & 16.90 & 16.14 & 19.59 & 25.59 & 40.40 \\
\hline $\mathrm{MnO}$ & - & - & 0.05 & 0.12 & 0.14 & 0.13 & 0.20 & 0.09 & 0.18 & 0.36 \\
\hline $\mathrm{MgO}$ & 0.07 & 0.18 & 0.24 & 11.21 & 10.23 & 13.03 & 13.63 & 11.46 & 9.93 & 0.06 \\
\hline $\mathrm{CaO}$ & 16.95 & 13.56 & 12.70 & 12.16 & 0.00 & 0.11 & 0.03 & 0.15 & 0.09 & 0.21 \\
\hline $\mathrm{Na}_{2} \mathrm{O}$ & 1.93 & 3.88 & 4.18 & 2.75 & 0.68 & - & - & - & - & - \\
\hline $\mathrm{K}_{2} \mathrm{O}$ & 0.06 & 0.07 & 0.16 & 0.91 & 8.88 & - & - & - & - & - \\
\hline $\mathrm{Cr}_{2} \mathrm{O}_{3}$ & - & - & - & - & - & 38.32 & 39.06 & 36.65 & 30.06 & 0.03 \\
\hline $\mathrm{Niō}$ & - & - & - & - & - & 0.13 & 0.12 & 0.08 & 0.19 & - \\
\hline \multirow[t]{2}{*}{ Total } & 98.87 & 100.57 & 100.28 & 100.12 & 96.90 & 100.30 & 100.55 & 100.42 & 99.37 & 97.30 \\
\hline & \multicolumn{3}{|c|}{ O-basis $=8$} & \multicolumn{2}{|c|}{ O-basis $=22$} & \multicolumn{5}{|c|}{ O-basis $=32$} \\
\hline $\mathrm{Si}$ & 2.22 & 2.36 & 2.42 & 5.93 & 5.66 & - & - & - & - & - \\
\hline Al & 1.73 & 1.61 & 1.53 & 2.38 & 2.45 & 6.68 & 6.02 & 5.73 & 4.88 & 0.25 \\
\hline $\mathrm{Ti}$ & - & - & - & 0.64 & 0.79 & 0.30 & 0.39 & 0.45 & 1.34 & 0.55 \\
\hline $\mathrm{Fe}^{3+}$ & 0.02 & 0.02 & 0.02 & - & - & 1.29 & 1.59 & 2.03 & 2.08 & 12.48 \\
\hline $\mathrm{Fe}^{2+}$ & - & - & - & 1.6 & 2.7 & 3.47 & 3.33 & 4.13 & 5.58 & 10.53 \\
\hline $\mathrm{Mn}$ & - & - & - & 0.02 & 0.02 & 0.03 & 0.04 & 0.02 & 0.04 & 0.10 \\
\hline $\mathrm{Mg}$ & 0.01 & 0.0 & 0.0 & & 2.39 & 4.77 & 5.01 & 4.30 & 3.86 & 0.03 \\
\hline $\mathrm{Ca}$ & 0.82 & 0.66 & 0.62 & 1.93 & 0.00 & 0.03 & 0.01 & 0.04 & 0.03 & 0.07 \\
\hline $\mathrm{Na}$ & 0.19 & 0. & 0.37 & 0. & 0.21 & - & - & - & - & \\
\hline K & 0.01 & 0.00 & 0.01 & 0.17 & 1.77 & - & - & - & - & - \\
\hline $\mathrm{Cr}$ & - & - & - & - & - & 7.44 & 7.62 & 7.30 & 6.20 & 0.01 \\
\hline$\Sigma$ & 4.00 & 4.00 & 3.99 & 16.00 & 16.01 & 24.01 & 24.01 & 24.00 & 24.01 & 24.02 \\
\hline An & 81 & 66 & 62 & & & & & & & \\
\hline
\end{tabular}

Note: All iron in feldspar calculated as $\mathrm{Fe}^{3+}$, as $\mathrm{Fe}^{2+}$ in kaersutite and biotite; $\mathrm{Fe}^{3+}$ in oxides calculated assuming cation sum of 24.00. Dash indicates concentration below detection limit. Analyses: 1 = single feldspar crystal $(585-48-1,130-133 \mathrm{~cm}) ; 2,3=$ feldspar in shards $(585 \mathrm{~A}-18-2,72-75 \mathrm{~cm}$; 585A-19-1, 42-45 cm); 4 = single keursutite crystal $(585-46-3,142-146 \mathrm{~cm}) ; 5$ = biotite in coarsely crystalline cpx-ilmenite-biotite aggregate $(585-55-2,78-82 \mathrm{~cm}) ; 6=$ transparent brown magnesiochromite in shard $(585-54-2,73-75 \mathrm{~cm}) ; 7$ = single magnesiochromite crystal $(585-46-3,142-146 \mathrm{~cm})$; 8 = magnesiochromite in replaced olivine shard (585A-19-1, $42-45 \mathrm{~cm}) ; 9$ = magnesiochromite in zeolitized olivine in shard in hyaloclastite clast (585A-19-2, 89-95 cm); $10=$ Ti-magnetite in shard in hyaloclastite clast $(585-19-2,89-95 \mathrm{~cm})$.

similar to those from tholeiites in Hawaii (Fodor et al., $1975)$, and are characterized by $\mathrm{Ti}$ contents of less than 0.025 formula units (f.u.) $\left(<0.9\right.$ wt. $\left.\% \mathrm{TiO}_{2}\right)$. Some "exceptional" crystals in shards of Samples 585A-18-2, 72$75 \mathrm{~cm}$ and 585A-19-1, 42-45 cm show $\mathrm{Ti}$ and $\mathrm{Al}$ contents identical to those in the $\mathrm{Ca}-, \mathrm{Al}-$, and Ti-enriched alkalic suite, but are characteristically enriched in total iron (Fig. 5). The pigeonitic rims of two crystals are interpreted as metastable products of rapid quenching of the tholeiitic magmas (cf. Evans and Moore, 1968).

The more $\mathrm{Ca}$ - and $\mathrm{Al}-$ rich pyroxene suite shows $\mathrm{Ti}$ contents of 0.02 to 0.05 formula units, some phenocrysts in shards (Samples 585-47-2, 83-85 cm and 585$55-2,78-82 \mathrm{~cm}$ ) reaching 0.08 f.u. ( 3 wt. $\% \mathrm{TiO}_{2}$ ), values which characterize pyroxenes crystallized from hawaiitic to mugearitic magmas on the Hawaiian Islands (Fodor et al., 1975). A single crystalline clast contains pyroxenes with $\mathrm{TiO}_{2}$ contents of up to $5.3 \mathrm{wt} . \%(0.15$ f.u.) which is similar to values found in Hawaiian nephelinites. Commonly, increasing $\mathrm{Ti}$ content is correlated with increasing total iron and alumina in the Ca-rich pyroxenes (Fig. 5; cf. Schweitzer et al., 1979).

\section{Magnesiochromites}

Magnesiochromite, ranging from 10 to $50 \mu \mathrm{m}$ in size, is a common accessory phase in all samples studied. It occurs as triangular or square-shaped euhedral crystals, and is associated with, or included within, olivine phenocrysts. All magnesiochromites are titaniferous, on the basis of about 30 microprobe analyses in 7 samples (Fig. 6 , Table 2). They differ significantly from MORB (Sigurdsson and Schilling, 1976; Wood et al., 1979), having higher amounts of replacement of $\mathrm{Cr}+\mathrm{Al}^{\text {by } \mathrm{Fe}^{3+}+}$ $\mathrm{Ti}$, and resemble those known from ocean-island tholeiitic (OIT) basalts (Evans and Wright, 1972).

\section{IImenite}

Euhedral ilmenite occurs in one zeolitized shard in the uppermost sample studied by microprobe (585-46-3, $142-146 \mathrm{~cm}$ ). Other occurrences in sedimentary units lower in Unit VI are confined to crystalline basaltic clasts.

\section{Titanomagnetite}

Titanomagnetite does not occur in shards, but is common in crystalline basaltic fragments.

\section{Amphibole and Mica}

Trace amounts of single anhedral crystals of kaersutitic amphibole and biotite occur in a few samples from Cores 42 to 55 of Hole 585 (Table 3; Samples 585-46-3, $142-146 \mathrm{~cm}, 585-54-2,144-147 \mathrm{~cm}, 585-55-2,78-82 \mathrm{~cm}$ ). 
Table 3. Microprobe analyses (wt. \%) of representative clinopyroxenes, Holes 585 and 585A.

\begin{tabular}{lrrrrrrrrrr}
\hline & \multicolumn{1}{c}{1} & \multicolumn{1}{c}{2} & \multicolumn{1}{c}{3} & \multicolumn{1}{c}{4} & \multicolumn{1}{c}{5} & \multicolumn{1}{c}{6} & \multicolumn{1}{c}{7} & \multicolumn{1}{c}{8} & 9 & 10 \\
\hline $\mathrm{SiO}_{2}$ & 54.48 & 52.64 & 52.38 & 52.17 & 51.82 & 49.61 & 51.28 & 50.22 & 46.69 & 43.33 \\
$\mathrm{Al}_{2} \mathrm{O}_{3}$ & 1.69 & 1.32 & 2.32 & 2.78 & 3.17 & 5.38 & 3.28 & 4.10 & 6.41 & 8.08 \\
$\mathrm{Cr}_{2} \mathrm{O}_{3}$ & 0.47 & 0.47 & 0.87 & 0.57 & 0.22 & 0.73 & 0.09 & 0.11 & 0.11 & 0.02 \\
$\mathrm{TiO}_{2}$ & 0.20 & 0.53 & 0.64 & 0.88 & 1.04 & 1.85 & 1.21 & 1.51 & 3.05 & 5.35 \\
$\mathrm{Fe}_{2} \mathrm{O}_{3}$ & 0.93 & 0.59 & 1.15 & 2.26 & 2.27 & 2.34 & 1.89 & 2.79 & 3.89 & 3.11 \\
$\mathrm{FeO}$ & 11.01 & 9.29 & 6.09 & 4.07 & 3.60 & 3.99 & 4.47 & 4.32 & 4.51 & 7.46 \\
$\mathrm{MnO}$ & 0.18 & 0.15 & 0.15 & 0.12 & 0.12 & 0.14 & 0.12 & 0.11 & 0.09 & 0.12 \\
$\mathrm{MgO}$ & 26.85 & 20.67 & 18.08 & 17.96 & 16.36 & 14.79 & 16.60 & 15.36 & 13.16 & 10.31 \\
$\mathrm{CaO}$ & 4.70 & 12.71 & 18.22 & 19.93 & 11.31 & 22.42 & 21.22 & 21.69 & 22.01 & 21.71 \\
$\mathrm{Na}_{2} \mathrm{O}$ & 0.06 & 0.20 & 0.30 & 0.31 & 0.32 & 0.36 & 0.23 & 0.39 & 0.51 & 0.62 \\
$\mathrm{Total}$ & 100.57 & 98.57 & 100.20 & 101.05 & 101.05 & 101.38 & 100.39 & 100.60 & 100.43 & 100.11
\end{tabular}

$(0)$ basis $=6$

\begin{tabular}{lllllllllll}
$\mathrm{Si}$ & 1.94 & 1.95 & 1.92 & 1.89 & 1.88 & 1.80 & 1.88 & 1.84 & 1.74 & 1.64 \\
$\mathrm{Al}$ & 0.06 & 0.05 & 0.08 & 0.11 & 0.12 & 0.20 & 0.12 & 0.16 & 0.26 & 0.36 \\
$\mathrm{Al}$ & 0.01 & 0.01 & 0.02 & 0.01 & 0.02 & 0.03 & 0.02 & 0.02 & 0.02 & 0.01 \\
$\mathrm{Cr}$ & 0.01 & 0.01 & 0.03 & 0.02 & 0.01 & 0.02 & 0.00 & 0.00 & 0.00 & 0.00 \\
$\mathrm{Ti}$ & 0.01 & 0.02 & 0.02 & 0.02 & 0.03 & 0.05 & 0.03 & 0.04 & 0.09 & 0.15 \\
$\mathrm{Fe} 3+$ & 0.03 & 0.02 & 0.03 & 0.06 & 0.06 & 0.06 & 0.05 & 0.08 & 0.11 & 0.09 \\
$\mathrm{Fe} 2+$ & 0.33 & 0.29 & 0.19 & 0.12 & 0.11 & 0.12 & 0.14 & 0.13 & 0.14 & 0.24 \\
$\mathrm{Mn}$ & 0.01 & 0.01 & 0.01 & 0.00 & 0.00 & 0.00 & 0.00 & 0.00 & 0.00 & 0.00 \\
$\mathrm{Mg}$ & 1.43 & 1.14 & 0.99 & 0.97 & 0.88 & 0.80 & 0.91 & 0.84 & 0.73 & 0.58 \\
$\mathrm{Ca}$ & 0.18 & 0.50 & 0.71 & 0.77 & 0.87 & 0.87 & 0.83 & 0.85 & 0.88 & 0.88 \\
$\mathrm{Na}$ & 0.00 & 0.01 & 0.02 & 0.02 & 0.02 & 0.03 & 0.02 & 0.03 & 0.04 & 0.05 \\
$\Sigma$ & 4.01 & 4.01 & 4.02 & 3.99 & 4.00 & 3.98 & 4.00 & 3.99 & 4.01 & 4.00 \\
& & & & & & & & & & \\
$\mathrm{Ca}$ & 9 & 26 & 37 & 40 & 46 & 47 & 43 & 45 & 47 & 49 \\
$\mathrm{Mg}$ & 73 & 58 & 51 & 51 & 45 & 43 & 47 & 44 & 39 & 33 \\
$\mathrm{Fe}^{3+} \mathrm{Fe}^{2+}$ & 18 & 16 & 11 & 9 & 9 & 10 & 10 & 11 & 13 & 18 \\
\hline
\end{tabular}

Note: $\mathrm{Fe}^{3+}$ calculated assuming cation sum of 4.000. Analyses: $1=$ in crystalline basaltic clast $(585 \mathrm{~A}-19-1,42-$ $45 \mathrm{~cm}) ; 2$ = in oxidized black shard $(585 \mathrm{~A}-19-1,42-45 \mathrm{~cm}) ; 3=\operatorname{single}$ crystal $(585 \mathrm{~A}-19-2,89-95 \mathrm{~cm}) ; 4=$ in shard (585A-18-2, 72-75 cm); 5, $6=$ in shard, core and rim of crystal $(585-46-3,142-146 \mathrm{~cm}) ; 7,8,9=$ in shards $(585-47-2,83-85 \mathrm{~cm}) ; 10=$ in oxidized dark shard $(585-55-2,78-82 \mathrm{~cm})$.

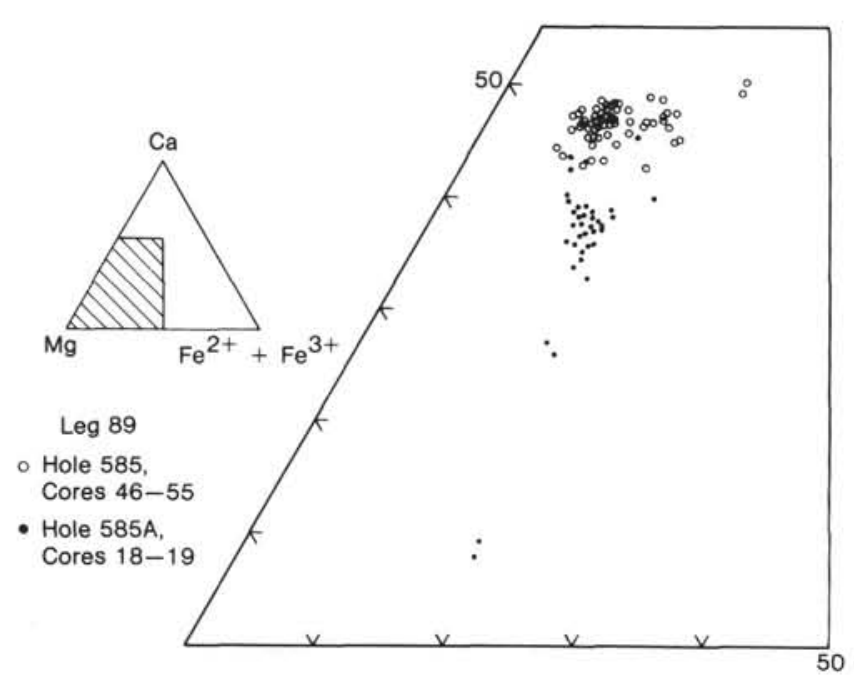

Figure 4. Chemical composition of clinopyroxenes in samples from lithologic Unit VI in the pyroxene quadrilateral. Open circles: Tirich clinopyroxenes, analyses of samples from Cores 46 to 55 , Hole 585; dots: analyses of samples from Cores 18 and 119, Hole 585A.

\section{Calcareous Clasts}

Calcareous skeletal debris of shallow-water organisms (fragments of mollusks, algae, echinoids, etc.) and ooids are common, making up as much as $12 \mathrm{vol} . \%$ of samples from the debris-flow sequence. The ooids, spanning a range of 150 to $900 \mu \mathrm{m}$ in diameter, are generally micritic, but some show primary radial calcitic struc-

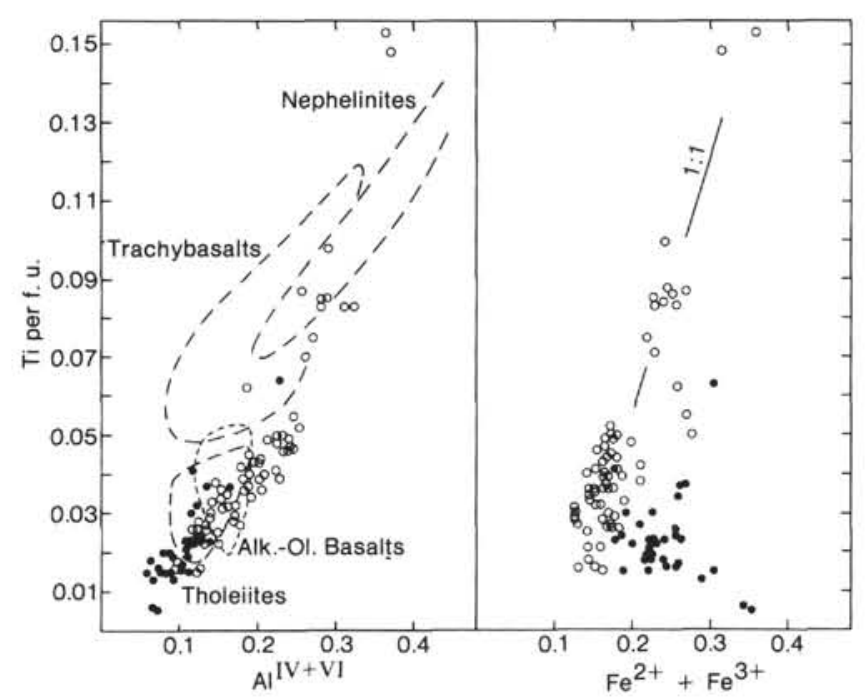

Figure 5. Distribution of clinopyroxenes from Site 585 in Ti-vs.-Al and Ti-vs.-Fe plots. Open circles: analyses of samples from Cores 46 to 55 , Hole 585; dots: analyses of samples from Cores 18 and 19 , Hole 585A. For comparison: fields of pyroxene compositions in different rock types from Hawaii (Fodor et al., 1975). Note more alkalic character of pyroxenes in Hole 585 .

tures within the distinct layering of the cortex. Most have calcareous cores. Only three examples of a volcanogenic core were found (clinopyroxene, olivine, and a former glass shard, the latter two now altered to sheet silicates), evidence that the volcanic input to the area at the time 


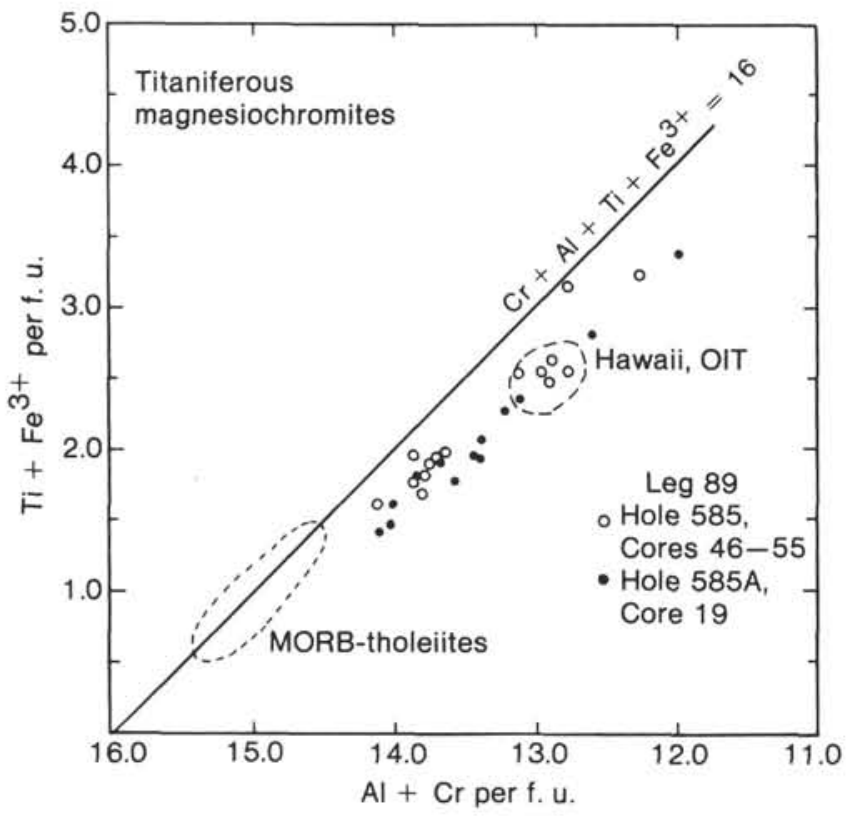

Figure 6. Variation of magnesiochromites in samples from Unit VI, Site 585 , in variation diagram of elements in 6-fold coordination (B-position). For comparison: fields of analyses of chromite in MORB-tholeiites (Sigurdsson and Schilling, 1976, and Wood et al., 1979) and Hawaiian tholeiites (OIT, Evans and Wright, 1972).

of ooid formation was small. In coarse-grained samples, some peloids or ooids are composite, held together by a thin rim of carbonate cement. Clasts of broken limestone (pelletal grainstone, in part with ooids) are mostly well rounded.

\section{Groundmass}

Most samples contain between 5 and 40 vol. $\%$ "groundmass," including primary matrix and cement. In some samples the high degree of alteration does not allow a separation of matrix from cement.

Abundant brownish to yellowish crypto-microcrystalline smectite or "palagonite" could have generally constituted former vitric matrix, which is likely to have been present in many samples, especially those without framework support. Relict shards, however, are rarely seen within this "matrix," and may be identified by former vesicle-filling spherulitic aggregates of radially oriented chlorite and chlorite/smectite fibers dispersed throughout a smectitic groundmass. However, electron microprobe analyses of areas within the brownish matrix that appears to be homogeneous show these to be composed of Ti-poor smectite, whereas larger altered glass shards are predominantly Ti-rich "palagonite" (Tables 4, 5). Thus, at least some of the smectitic/palagonitic groundmass may as well be regarded as cement.

\section{STRATIGRAPHIC DISTRIBUTION OF ROCK TYPES}

Volcaniclastic rocks of Unit VI (Site 585) are dominantly mass-flow deposits, as shown by characteristic sedimentary structures. Sediments of the lower debrisflow sequence are typically poorly sorted and bedded and in part extremely coarse-grained (up to boulder-size clasts).
Table 4. Representative microprobe analyses (wt.\%) of palagonitetype altered glass shards.

\begin{tabular}{lrrrrcccc}
\hline & 1 & \multicolumn{1}{c}{2} & \multicolumn{1}{c}{3} & \multicolumn{1}{c}{4} & 5 & 6 & 7 & 8 \\
\hline $\mathrm{SiO}_{2}$ & 33.42 & 31.99 & 32.94 & 34.83 & 32.04 & 23.93 & 34.25 & 31.68 \\
$\mathrm{TiO}_{2}$ & 0.16 & 2.30 & 4.57 & 6.37 & 9.22 & 13.12 & 18.75 & 32.17 \\
$\mathrm{Al}_{2} \mathrm{O}_{3}$ & 7.52 & 6.29 & 10.84 & 7.19 & 5.13 & 3.42 & 6.46 & 3.90 \\
$\mathrm{FeO}$ & 11.25 & 11.84 & 12.27 & 11.89 & 9.26 & 5.82 & 7.06 & 2.45 \\
$\mathrm{MnO}$ & 0.11 & 0.02 & 0.26 & 0.07 & 0.16 & 0.07 & 0.17 & - \\
$\mathrm{MgO}$ & 13.25 & 10.92 & 15.32 & 11.91 & 7.48 & 3.39 & 2.36 & - \\
$\mathrm{CaO}$ & 1.35 & 3.66 & 5.07 & 7.29 & 10.96 & 12.78 & 6.33 & 28.75 \\
$\mathrm{Na}{ }_{2} \mathrm{O}$ & 1.33 & 0.76 & 0.62 & 2.03 & 0.89 & 0.81 & 1.74 & 0.18 \\
$\mathrm{~K}_{2} \mathrm{O}$ & 0.15 & 0.03 & 0.04 & - & 0.05 & - & 1.11 & 0.04 \\
$\mathrm{Cr}_{2} \mathrm{O}_{3}$ & 0.06 & - & 0.07 & - & 0.05 & 0.04 & 0.15 & 0.01 \\
$\mathrm{NiO}$ & 0.04 & n.a. & 0.12 & n.a. & n.a. & n.a. & - & 0.05 \\
Total & 68.64 & 67.87 & 82.12 & 81.58 & 75.24 & 63.38 & 78.39 & 99.27 \\
\hline
\end{tabular}

Note: All iron calculated as $\mathrm{Fe}^{2+}$. Dash indicates concentration below detection limit. Analyses: 1 = light brown yellowish crypto- to microcrystalline rim around vesicle in dominantly zeolitized shard $(585-48-1,130-133 \mathrm{~cm})$; 2 = brown-yellow cryptocrystalline(?) shard, isotropic to weakly birefringent (585A-19-1, $42-45 \mathrm{~cm}) ; 3$ = brown-green yellowish shard, isotropic to weakly undulous birefringent $(585-46-3,142-146 \mathrm{~cm}) ; 4=$ reddish brown central part of a zoned altered shard, isotropic, strongly "curdled" (585-48-1, $32-36 \mathrm{~cm}) ; 5$ = light red-brown yellowish shard, weak undulous extinction (585A-19-1, 42-45 cm); 6 = yellowish brownish zone around brown-yellow central part of a shard, nearly isotropic $(585-48-1,32-36 \mathrm{~cm}) ; 7=$ microcrystalline brown sphere of about $8 \mu \mathrm{m}$ diameter within zeolitized central part of a shard (see Fig. 10) $(585-49-2,108-110 \mathrm{~cm}) ; 8$ = sphene crystal in crystalline basaltic clast $(585-48-1,32-36 \mathrm{~cm})$.

Nine samples of the debris-flow sequence were studied, spanning an interval of about $38 \mathrm{~m}$. The lowermost sample of a coarse-grained, poorly sorted part of this sequence $(585 \mathrm{~A}-19-2,89-95 \mathrm{~cm})$ is an inhomogeneous volcanogenic breccia composed of shards, crystalline basalt, tachylite, hyaloclastite fragments, and minor calcareous fragments of shallow-water organisms and limestone in a formerly vitric matrix. Vitric clasts are mostly blocky, but some scoria shards are present. Shards of the matrix are the spalling type, as are those in the hyaloclastite fragments.

Six samples from above the breccia are vitric tuffs showing a continuous upsection decrease in grain size (medium grain size in Sample 585A-19-1, 42-45 cm: $1000 \mu \mathrm{m}$; in $585 \mathrm{~A}-18-2,72-75 \mathrm{~cm}: 500 \mu \mathrm{m}$; in $585 \mathrm{~A}-$ $17-1,11-14 \mathrm{~cm}: 250 \mu \mathrm{m})$, and this decrease is accompanied by decreasing amounts of matrix (from about 30 vol. $\%$ in the lowermost sample to no matrix in the upper samples). Shards in the lower part of this graded unit are commonly vesicle-poor and blocky ( $>90 \mathrm{vol} . \%$ of vitrics), whereas the upper samples (585A-17-1, 11$14 \mathrm{~cm}$ and $585 \mathrm{~A}-16, \mathrm{CC}$ ) are dominated by scoria or vesicular blocky and bubble-wall shards. Lithic clasts are commonly tachylite, and generally comprise less than 15 vol. \%. The amount of carbonate debris, including accessory limestone clasts, remains relatively constant (8$12 \mathrm{vol} . \%$ ) throughout these samples, and grain sizes are similar to those of the volcanic clasts.

The two uppermost samples of the debris-flow sequence $(585 \mathrm{~A}-16-3,37-39 \mathrm{~cm}$ and $585 \mathrm{~A}-16-4,78-81 \mathrm{~cm})$ are vitric tuffs with rock fragments of tuff ("intraclast tuffs") composed mainly of spalling shards. These fragments may be more than $5 \mathrm{~mm}$ long, and are quite regularly dispersed throughout. Grain sizes of formerly vitric particles within the tuffaceous clasts $(<30 \mu \mathrm{m})$ are much smaller than the "primary" spalling shards, and average about 100 to $160 \mu \mathrm{m}$. 
Table 5. Representative microprobe analyses (wt.\%) of sheet silicates, Holes 585 and 585A.

\begin{tabular}{|c|c|c|c|c|c|c|c|c|c|c|c|c|c|}
\hline & \multicolumn{4}{|c|}{ Chlorite } & \multicolumn{4}{|c|}{ Chlorite/smectite } & \multicolumn{2}{|c|}{ Smectite } & \multirow{2}{*}{$\frac{\text { Sme/ill }}{11}$} & \multicolumn{2}{|c|}{ Celadonite } \\
\hline & 1 & 2 & 3 & 4 & 5 & 6 & 7 & 8 & 9 & 10 & & 12 & 13 \\
\hline $\mathrm{SiO}_{2}$ & 28.34 & 29.58 & 30.11 & 31.54 & 39.12 & 39.26 & 40.57 & 41.08 & 38.98 & 37.15 & 48.15 & 45.59 & 45.42 \\
\hline $\mathrm{Al}_{2} \mathrm{O}_{3}$ & 17.63 & 14.02 & 14.74 & 12.07 & 11.96 & 8.73 & 9.15 & 7.43 & 8.53 & 9.64 & 19.44 & 7.25 & 4.99 \\
\hline $\mathrm{TiO}_{2}$ & 0.03 & 0.16 & 0.03 & 0.04 & 0.14 & 0.32 & 0.05 & - & 0.11 & 0.43 & 0.05 & 0.09 & 0.04 \\
\hline $\mathrm{FeO}^{2}$ & 23.98 & 28.77 & 25.77 & 30.39 & 18.92 & 16.84 & 18.40 & 16.60 & 13.11 & 15.54 & 6.37 & 23.53 & 23.53 \\
\hline $\mathrm{MnO}$ & 0.14 & 0.59 & 0.21 & 0.18 & 0.18 & 0.12 & 0.07 & 0.09 & 0.11 & 0.07 & 0.08 & 0.03 & 0.08 \\
\hline $\mathrm{MgO}$ & 16.75 & 15.07 & 14.45 & 12.51 & 15.95 & 15.86 & 15.25 & 13.42 & 12.50 & 10.21 & 4.28 & 4.26 & 4.02 \\
\hline $\mathrm{CaO}$ & 0.32 & 0.48 & 0.47 & 0.61 & 1.87 & 0.31 & 0.70 & 1.27 & 2.05 & 2.97 & 1.16 & 1.36 & 0.88 \\
\hline $\mathrm{Na}_{2} \mathrm{O}$ & 0.17 & 0.30 & 0.31 & 0.69 & 0.97 & 3.33 & 3.28 & 2.00 & 1.28 & 1.78 & 0.59 & 0.63 & 0.28 \\
\hline $\mathrm{K}_{2} \mathrm{O}$ & 0.02 & 0.03 & - & 0.27 & 0.69 & 0.01 & 0.03 & 0.05 & 0.25 & 0.61 & 6.79 & 6.75 & 6.90 \\
\hline $\mathrm{Cr}_{2} \mathrm{O}_{3}$ & - & 0.01 & 0.06 & 0.01 & 0.02 & 0.08 & 0.06 & 0.02 & 0.07 & 0.03 & - & - & - \\
\hline $\mathrm{NiO}$ & 0.01 & - & 0.22 & - & 0.14 & 0.02 & 0.19 & - & n.a. & n.a. & n.a. & n.a. & n.a. \\
\hline \multirow[t]{2}{*}{ Total } & 87.48 & 89.01 & 86.37 & 89.31 & 89.96 & 84.88 & 87.75 & 81.96 & 76.98 & 78.43 & 86.93 & 89.50 & 86.19 \\
\hline & \multicolumn{4}{|c|}{ O-basis $=28$} & \multicolumn{9}{|c|}{ O-basis $=22$} \\
\hline $\mathrm{Si}$ & 5.94 & 6.27 & 6.45 & 6.71 & 5.60 & 5.82 & 5.87 & 6.45 & 6.51 & 6.15 & 7.18 & 6.97 & 7.28 \\
\hline $\mathrm{Al}$ & 2.06 & 1.73 & 1.55 & 1.29 & 2.02 & 1.53 & 1.56 & 1.38 & 1.49 & 1.85 & 0.82 & 1.03 & 0.72 \\
\hline Al & 2.27 & 1.77 & 2.17 & 1.74 & - & & & - & 0.19 & 0.03 & 2.60 & 0.28 & 0.22 \\
\hline $\mathrm{Ti}$ & 0.01 & 0.03 & 0.01 & 0.01 & 0.02 & 0.04 & 0.01 & 0.00 & 0.01 & 0.05 & 0.01 & 0.01 & 0.00 \\
\hline $\mathrm{Fe}$ & 4.27 & 5.10 & 4.62 & 5.40 & 2.26 & 2.09 & 2.23 & 2.18 & 1.83 & 2.15 & 0.79 & 3.01 & 3.15 \\
\hline Mn & 0.04 & 0.11 & 0.04 & 0.03 & 0.02 & 0.02 & 0.01 & 0.01 & 0.02 & 0.01 & 0.01 & 0.00 & 0.01 \\
\hline $\mathrm{Mg}$ & 5.17 & 4.76 & 4.61 & 4.28 & 3.40 & 3.51 & 3.29 & 3.14 & 3.11 & 2.52 & 0.95 & 0.97 & 0.96 \\
\hline $\mathrm{Ca}$ & 0.08 & 0.11 & 0.11 & 0.14 & 0.29 & 0.05 & 0.11 & 0.21 & 0.37 & 0.53 & 0.19 & 0.22 & 0.15 \\
\hline $\mathrm{Na}$ & 0.11 & 0.12 & 0.13 & 0.28 & 0.27 & 0.96 & 0.92 & 0.61 & 0.41 & 0.57 & 0.17 & 0.19 & 0.09 \\
\hline K & 0.01 & 0.01 & - & 0.07 & 0.13 & 0.00 & 0.01 & 0.01 & 0.05 & 0.13 & 1.29 & 1.32 & 1.41 \\
\hline$\Sigma Z$ & 8.00 & 8.00 & 8.00 & 8.00 & 7.62 & 7.35 & 7.44 & 7.83 & 8.00 & 8.00 & 8.00 & 8.00 & 8.00 \\
\hline$\Sigma Y$ & 11.96 & 12.01 & 11.69 & 11.95 & 5.70 & 5.66 & 5.53 & 5.33 & 5.16 & 4.76 & 4.36 & 4.27 & 4.34 \\
\hline$\Sigma X$ & - & - & - & - & 0.69 & 1.01 & 1.03 & 0.83 & 0.83 & 1.23 & 1.65 & 1.73 & 1.65 \\
\hline
\end{tabular}

Note: Total iron calculated as $\mathrm{Fe}^{2+}$. Analyses: 1 = chlorite replacing olivine in crystalline basaltic clast $(585-47-2,83-85 \mathrm{~cm})$; 2 = chlorite, vesicle filling, outer fibrous zone $(585-48-1,32-36 \mathrm{~cm}) ; 3$ = chlorite, replacing olivine, rim $(585-54-2,73-$ $75 \mathrm{~cm}) ; 4$ = chlorite, central vesicle-filling $(585-55-2,78-82 \mathrm{~cm}) ; 5-8=$ chlorite/smectite mixed minerals: $5=$ chlorite/ smectite, same vesicle as 4 , mantle ( $585-55-2,78-82 \mathrm{~cm}) ; 6=$ chlorite/smectite, same vesicle as 2 , inner fibrous zone (58548-1, 32-36 cm); 7 = chlorite/smectite, replacing same olivine as 3, core $(585-54-2,73-75 \mathrm{~cm}) ; 8=$ chlorite $/$ smectite, vesicle filling, core (585A-19-2, 89-95 cm); $9,10=$ smectite, cryptocrystalline cement, or thoroughly altered vitric matrix $(585-49-2,108-110 \mathrm{~cm}) ; 11=$ smectite/illite mixed minerals, last vesicle-filling phase $(585-46-3,142-146 \mathrm{~cm}) ; 12=$ celadonite, void-filling $(585-48-1,130-133 \mathrm{~cm}) ; 13$ = celadonite, replacing shard $(585 \mathrm{~A}-19-2,89-95 \mathrm{~cm}) ;-$ indicates concentration below detection limit.

The upper turbidite sequence is characterized by abundant single-flow units, tens of centimeters to $2 \mathrm{~m}$ thick, commonly with complete Bouma cycles at least up to Core 46 (Hole 585; about $667 \mathrm{~m}$ depth), and with interlayered pelagic sediments.

The turbidite sequence can be stratigraphically divided into two lithologically different groups. A lower group of heterogeneous lithic- and crystal-rich rocks (Hole 585, Cores 49-55) contains spalling, bubble-wall, and slightly vesicular scoria shards. All vitric clasts show considerable rounding. The rocks contain up to $30 \mathrm{vol} . \%$ lithic, commonly well-rounded clasts of basalt and hawaiite/ mugearite, as well as slightly angular tachylite with up to 15 vol. \% vesicles. Crystal clasts constitute up to 10 vol. $\%$ and are mostly clinopyroxene, followed by olivine and minor plagioclase. The good rounding indicates the largely epiclastic nature of the fragmentation processes. The upper vitric tuffs (Cores 42-49 of Hole 585) are more pyroclastic, as suggested by abundant vesicular shards (scoria and bubble-wall) and angularity of clasts. One turbidite unit of Section 585-49-2, $(45-110 \mathrm{~cm})$, sampled in detail, shows a distinct decrease in medium grain size, from about $400 \mu \mathrm{m}$ at the base (Sample 585$49-2,108-110 \mathrm{~cm}$ ) to $80 \mu \mathrm{m}$ in the upper part (Sample $585-49-2,46-48 \mathrm{~cm})$. This unit (50-60 vol.\% shards) is composed mainly of vesicular scoria $(30-50 \mathrm{vol} . \%$ vesi- cles), which range up to lapilli size $(>4 \mathrm{~mm})$ near the base. Vesicles are round to ovoid, with sizes up to $1 \mathrm{~mm}$ in the largest shards; medium sizes range from about 400 to $500 \mu \mathrm{m}$.

\section{ALTERATION}

The time dependence and site dependence of low-temperature alteration processes are especially pronounced in compositionally heterogeneous rocks such as the volcaniclastics studied. In a later section we will therefore describe the secondary mineral assemblages at various sites; but first we discuss the optical and chemical variations of individual phases.

\section{Secondary Minerals}

\section{Sheet Silicates}

\section{Palagonite}

Yellow to dark brown, isotropic to weakly undulose palagonite is the most common alteration phase of shards throughout the rocks of Unit VI. It varies widely in chemical composition (Table 4, Figs, 7, 8). Palagonite represents an early alteration stage of intimately mixed cryptocrystalline minerals. Shards are discussed in more detail later, under Alteration Sites. 


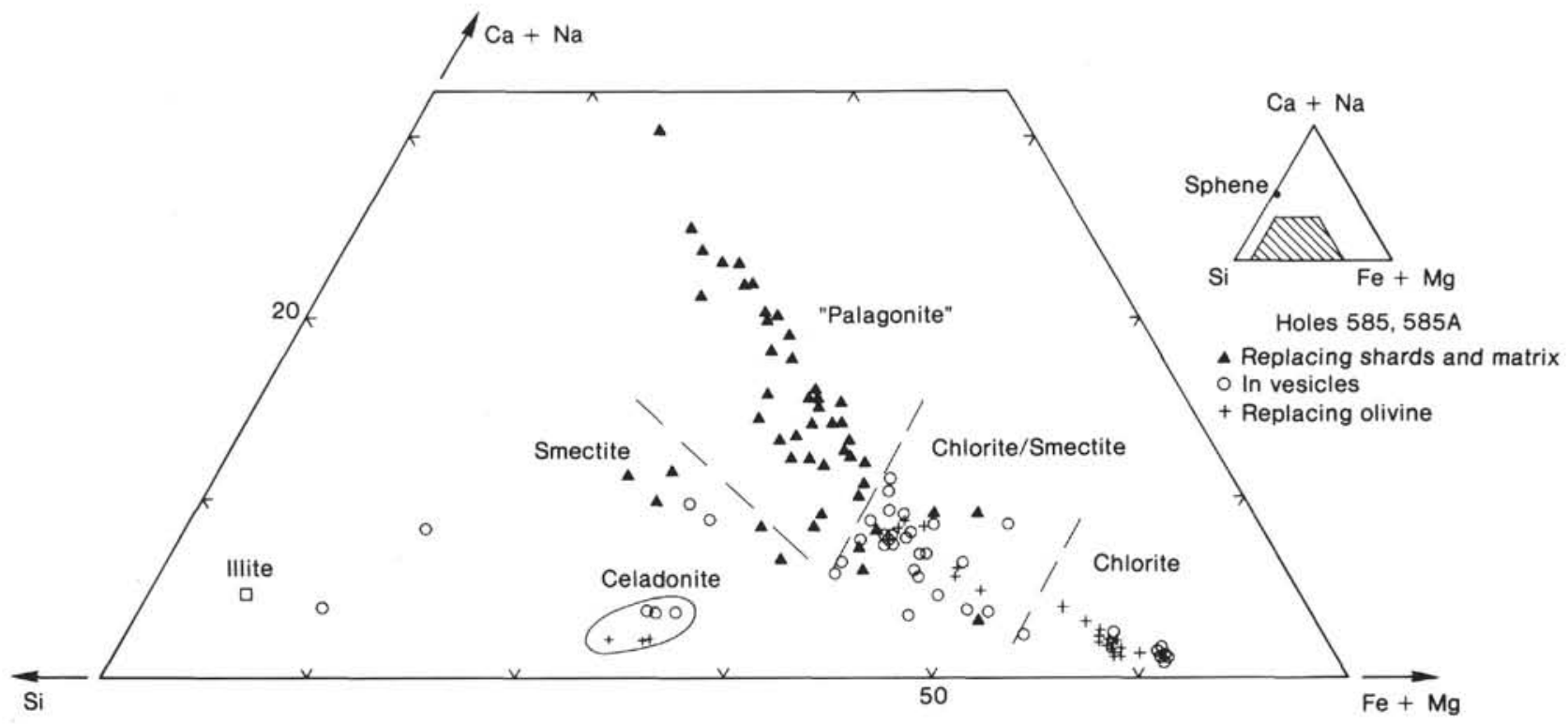

Figure 7. Compositional variations of sheet silicates and palagonite in volcaniclastic rocks, Unit VI, Site 585, shown in $(\mathrm{Ca}+\mathrm{Na})-\mathrm{Si}-(\mathrm{Fe}+$ $\mathrm{Mg}$ ) plot. Reference analyses of illite and sphene from Deer et al. (1964a). Note compositional trend of palagonite toward sphene composition (reference point in triangle).

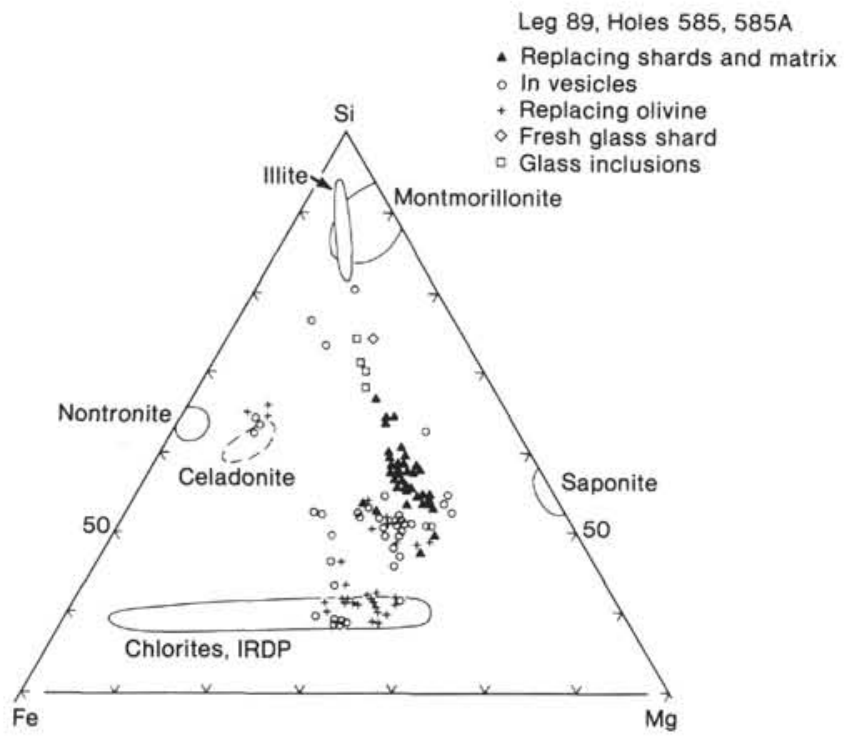

Figure 8. Si-Fe-Mg plot of sheet silicates in distinctive sites in volcaniclastic sediments of Unit VI, Site 585. Fields for reference minerals from Deer et al. (1964a: illite, montmorillonite, nontronite, saponiite), Viereck et al. (1982: chlorite of the Iceland Research Drilling Project, IRDP), and Andrews (1980: celadonite). Note linear variation trend of palagonite and smectite analyses in shards toward compositions of glass inclusions and glass shard (Table 11).

\section{Smectite}

Smectites are less common than palagonite, analcite, or chlorite/smectite mixed minerals. They are characteristically yellow-brown to ochre and nonpleochroic, with low, first-order birefringence. We use the term smectite only for those sheet silicates that show these characteristics and are chemically characterized by $(\mathrm{Si}+\mathrm{Al})>$ 8 ions per formula unit (on the basis of 22 oxygens, Table 5). They generally occur in cryptocrystalline to scaly aggregates as cement, in the matrix, and in shards. They commonly form early coatings less than $4 \mu \mathrm{m}$ thick in vesicles.

\section{Smectite/Illite Mixed Minerals}

Potassium-enriched light yellow-brown cryptocrystalline smectites are restricted to Cores 42 and 43 of Hole 585 (Table 1). Both samples are fine-grained vitric tuffs in which smectite/illite occurs as cement and alteration product of shards. In Sample 585-46-3, 142-146 cm, greenish yellow-brown vesicle fillings show increasing potassium contents toward the centers (see analysis 11, Table 5).

\section{Celadonite}

Celadonite occurs only in trace amounts in various samples, and is always confined to single clasts. This indicates the importance of specific microenvironmental conditions favoring the formation of this $\mathrm{K}-\mathrm{Fe}$-rich sheet silicate. Celadonite forms microcrystalline, scaly to fibrous nonpleochroic aggregates in shades of green and yellow, masking first-order birefringence, and is thus easily confused with chlorite. The celadonites analyzed have a narrow compositional range (Figs. 7,8 ) and generally lower $\mathrm{SiO}_{2}$ contents than those from Leg 37 reported by Andrews (1980) or those from continental environments reported by Foster (1969).

\section{Chlorite/Smectite Mixed Minerals}

Chlorite/smectite mixed minerals (m.m.) are intermediate optically and chemically between smectites and chlorites (Fig. 7). They are coarse crystalline fibers (length $<130 \mu \mathrm{m}$ ) with strong brown-green to yellow-brown pleochroism, relatively high relief and birefringence ( $n$ $<0.025$ ), and some concentration of opaque phases along crystal boundaries. They differ chemically from 
chlorites in having higher $\mathrm{Si}$ and $(\mathrm{Ca}+\mathrm{Na})$, lower concentrations of $\mathrm{Al}, \mathrm{Fe}$, and $\mathrm{Mg}$, and lower totals (Table 5). They differ from smectites by having less $(\mathrm{Si}+\mathrm{Al})$ than necessary to fill the $Z$-position in the crystal structure to 8 if calculated on the basis of 22 oxygens (Table 5). The petrographic and microprobe data show this group to be a gradational sequence of mixed minerals having increasingly brownish pleochroism and birefringence, correlated with increasing smectite component, which is characterized by increasing $\mathrm{Si},(\mathrm{Ca}+\mathrm{Na})$, and water. They constitute the dominant mineral phase in vesicles, but are less common in shards and pores, postdating smectite and chlorite and predating chlorite, zeolites (analcite, chabazite, and natrolite), and carbonate in olivine and plagioclase.

\section{Chlorite}

Chlorites are much less common than chlorite/smectite m.m. They are typically developed as microcrystalline fibrous seams or aggregates, about $20 \mu \mathrm{m}$ in size, with strong pleochroism from yellow- to grass-green, which masks first-order birefringence colors. Anomalous interference colors were not found. Electron microprobe analyses of about 20 chlorites show a compressional range from pycnochlorites to dibantites, with $\mathrm{Si}$ varying from 5.9 to 6.7 ions formula unit at $\mathrm{Fe}^{2+} / \mathrm{Fe}^{2+}$ $+\mathrm{Mg}$ ratios of 40 to 55 (Table 5). Chlorites predate chlorite/smectite m.m. in vesicles and postdate them in olivines.

\section{Zeolites}

Zeolites make up the second most common secondary mineral phase next to palagonite. They replace former vitric shards, olivine, and plagioclase, and also occur in primary and secondary pores.

\section{Analcite}

The most common zeolite in all samples is analcite. Optically, two types of analcite are distinguished, both completely isotropic.

1. Clear analcite occurs mostly as replacement of phenocrysts and palagonitic shards (Plate 3, Fig. 1).

2. "Dusty," inclusion-rich analcite is more common in primary pore-space, where it replaces a prismatic phase, in part fringing particles as a rim cement. Moreover, "dusty" analcite occurs as marginal shard replacement where it has completely replaced an earlier alteration phase, which itself has replaced palagonite (Plate 5, Fig. 2). Judging from the needle-shaped crystal habit and occurrence as an early alteration product of basaltic vitric tuffs, the replaced alteration phase most probably was phillipsite. The boundary of marginal shard-replacing "dusty" analcite toward palagonitic parts of a shard is always irregular and shows scalloped surfaces (Plate 5, Fig. 2), whereas the boundary between palagonite and clear analcite is smooth. The latter boundary may be developed either as a sharp delineation between the two phases or as a gradual transition with increasing amounts of palagonite inclusions (most $<1 \mu \mathrm{m}$ ) within analcite toward the palagonitic part of the shard. Both types of analcite-palagonite transitions can occur within one shard.
Chemically, there is no systematic difference between clear and "dusty" analcite, except for clear plagioclasereplacing analcite, which is compositionally homogeneous (Fig. 9, Table 6). $\mathrm{Si} / \mathrm{Al}$ ratios of analcites vary from 1.9 to 2.5 , but are mostly around 2.1 to 2.3 . Si increases slightly from $<2.0$ to about 2.1 per formula unit with

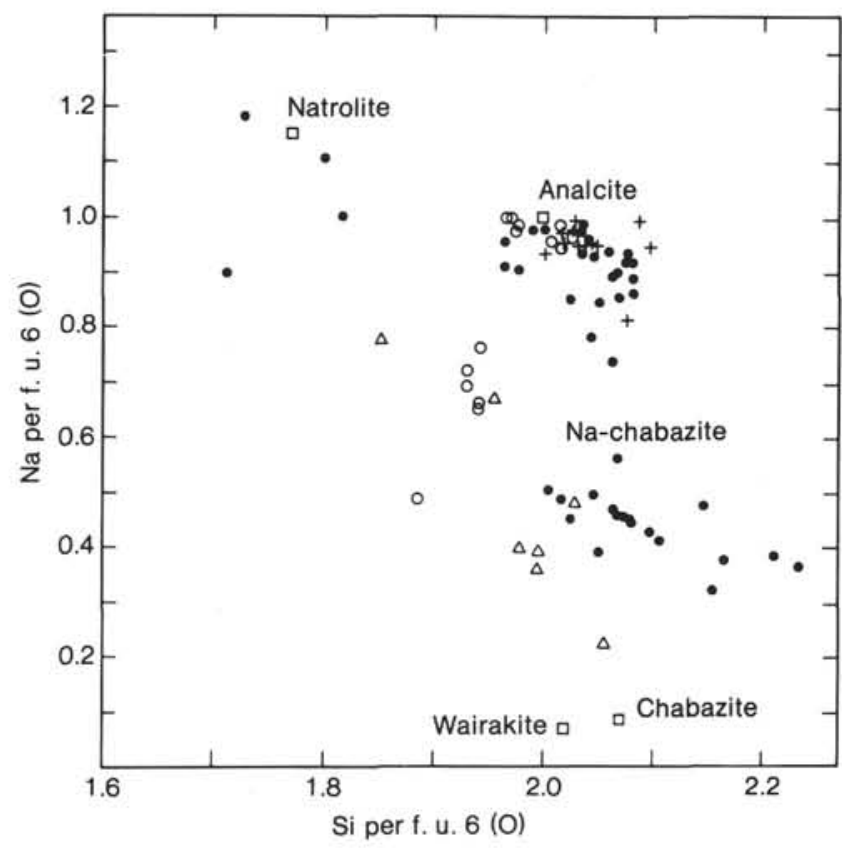

Figure 9. Compositional variation of $\mathrm{Na}(\mathrm{Ca})$-zeolites in samples from Unit VI, Site 585. Crosses: replacing plagioclase; circles: shards replacement, pore cement, and vesicle filling; open circles: Sample 585-47-2, 83-85 cm; filled circles: all other samples from Core 46, Hole 585 , to Core 19 , Hole 585A. Open squares: reference analyses from Deer et al. (1964b). Open triangles: Na-rich chabazites in Iijima and Harada (1968) and Passaglia (1970). Note general depletion of $\mathrm{Si}$ with increasing $\mathrm{Na}$ content in $\mathrm{Na}$-chabazites.

Table 6. Microprobe analyses (wt.\%) of representative zeolites, Holes 585 and $585 \mathrm{~A}$.

\begin{tabular}{|c|c|c|c|c|c|c|c|c|c|c|}
\hline & \multicolumn{3}{|c|}{ Natrolite } & \multicolumn{4}{|c|}{ Na-chabazite } & \multicolumn{3}{|c|}{ Analcite } \\
\hline & 1 & 2 & 3 & 4 & 5 & 6 & 7 & 8 & 9 & 10 \\
\hline $\mathrm{SiO}_{2}$ & 46.39 & 47.28 & 49.8 & 50.13 & 50.33 & 53.7 & 56.64 & 55.8 & 55.95 & 56.03 \\
\hline $\mathrm{TiO}_{2}$ & - & - & - & 0.05 & 0.05 & 0.02 & - & - & 0.02 & - \\
\hline $\mathrm{Al}_{2} \mathrm{O}_{3}$ & 29.89 & 26.74 & 28.6 & 23.19 & 23.30 & 20.91 & 20.36 & 23.47 & 22.25 & 23.22 \\
\hline $\mathrm{FeO}$ & 0.07 & 0.16 & 0.05 & 0.04 & 0.36 & - & 0.06 & 0.14 & 0.06 & 0.02 \\
\hline $\mathrm{MnO}$ & - & - & - & - & - & - & 0.02 & - & 0.01 & - \\
\hline $\mathrm{MgO}$ & - & - & 0.03 & 0.01 & - & - & - & - & - & - \\
\hline $\mathrm{CaO}$ & 4.27 & 0.84 & 0.11 & 6.22 & 4.32 & 7.00 & 5.86 & 0.07 & 0.04 & 0.01 \\
\hline $\mathrm{Na}_{2} \mathrm{O}$ & 12.76 & 16.67 & 15.74 & 6.62 & 9.71 & 5.17 & 5.76 & 14.2 & 13.99 & 13.99 \\
\hline $\mathrm{K}_{2} \mathrm{O}$ & - & - & 0.03 & 0.34 & 0.36 & 0.32 & 0.18 & - & 0.01 & 0.01 \\
\hline \multirow[t]{2}{*}{ Total } & 93.38 & 91.69 & 94.36 & 86.60 & 88.43 & 87.12 & 88.88 & 93.36 & 92.36 & 93.28 \\
\hline & \multicolumn{3}{|c|}{ O-basis: 10} & \multicolumn{7}{|c|}{ O-basis: 6} \\
\hline $\mathrm{Si}$ & 2.85 & 2.98 & 3.01 & 1.89 & 1.93 & 2.05 & 2.11 & 2.00 & 2.04 & 2.02 \\
\hline Al & 2.17 & 1.98 & 2.04 & 1.03 & 1.05 & 0.94 & 0.89 & 0.99 & 0.95 & 0.96 \\
\hline $\mathrm{Ca}$ & 0.28 & 0.06 & 0.01 & 0.25 & 0.18 & 0.29 & 0.23 & - & 0.01 & - \\
\hline $\mathrm{Na}$ & 1.52 & 2.03 & 1.84 & 0.48 & 0.72 & 0.38 & 0.42 & 0.99 & 0.99 & 0.98 \\
\hline K & - & - & - & 0.03 & 0.02 & 0.02 & 0.01 & - & - & - \\
\hline
\end{tabular}

Note: all iron calculated at $\mathrm{Fe}^{2+}$. Dash indicates concentration below detection limit. Analysis: 1 = radiating needles of natrolite, replacing parts of former vitric shard $(585-55-2,78-82 \mathrm{~cm})$; $2=$ radiating needles of natrolite, intraparticle cement within dissolved erystal clast (585$48-1,32-36 \mathrm{~cm}$ ); 3 = "platy" natrolite, replacing shard or crystal clast? (585-46-3, 142$146 \mathrm{~cm}) ; 4=$ clear crystal of blocky, pore-filling cement of Na-chabazite $(585-47-2,83-85 \mathrm{~cm}$ ); $5=$ blocky shard-replacing Na-chabazite $(585-47-2,83-85 \mathrm{~cm}) ; 6=$ blocky cement of $\mathrm{Na}$ chabazite, rimming particles; clear, very weakly birefringent crystal $(585 \mathrm{~A}-19-2,89-85 \mathrm{~cm})$; $7=$ mosaic of blocky Na-chabazite filling central part of a vesicle in former vitric shard (585. $55-2,78-82 \mathrm{~cm}) ; 8$ = clear shard-replacing analcite $(585-55-2,78-82 \mathrm{~cm}) ; 9=$ clear analcite filling vesicle in former glass shard (no crystal faces) $(585-48-1,130-133 \mathrm{~cm}) ; 10=$ clear analcite, replacing part of former vitric shard, same shard as 1, close to natrolite of analysis 1 (585-55-2, 78-82 cm). 
decreasing $\mathrm{Na}$ (from about 1.0 to about 0.8 per formula unit).

\section{Chabazite}

Chabazite, the second most abundant zeolite, occurring in all samples except 585-46-3, 142-146 cm, is much more common as cement than is analcite. In vesicles, where analcite is almost absent, clear chabazite postdates sheet silicates and completely fills the remaining porespace. Chabazite occurs as a mosaic of irregular crystals, in part with complex twinning. Its birefringence varies from nearly isotropic to medium gray. Temporal relations between chabazite and former phillipsite (now analcite) are not always clear, but chabazite seems to postdate phillipsite and predate analcite. Chabazite also commonly occurs in central parts of shards, where it contains abundant inclusions of minute unidentifiable "dust" and relatively large spherules of leucoxene (Plate 4).

Chabazite is highly variable chemically (Table 6), with $\mathrm{Na}$ ranging from 0.3 to 0.75 per formula unit (structural formula calculated for 6 oxygen atoms per formula unit) and $\mathrm{Si}$ from 1.9 to $<2.2$ per f.u. $\mathrm{Si} / \mathrm{Al}$ ratios range from 1.8 to 2.5 . In spite of the high Na contents, the XRD pattern is typical (Gude and Shepperd, 1966). Increasing $\mathrm{Na}$ contents correlate well with decreasing $\mathrm{Si}$ (Fig. 9), indicating coupled replacement of $\mathrm{Na}+\mathrm{Al}$ for $\mathrm{Si}+\mathrm{Ca}$.

Na-rich chabazite has been reported in zeolitic palagonite tuffs from Oahu, Hawaii (Iijima and Harada, 1968), where chabazite, together with phillipsite, forms the principal cement, always postdating phillipsite and predating analcite. Several other occurrences of Na-rich chabazite in igneous rocks reflect a nearly complete solid-solution series between $\mathrm{Na}$ and $\mathrm{Ca}$ end-members (Passaglia, 1970).

\section{Natrolite}

Natrolite was found in only a few samples of the upper sequence, in aggregates of radiating fibers and less commonly as platy vesicles, crystal clasts (olivine and rarely plagioclase), and as cement in primary pore-space. Natrolite cement always postdates chabazite and rarely replaces phillipsite. Natrolite in former olivine and in vesicles follows sheet silicates, and is partly intergrown with calcite (Sample 585-48-1, 32-36 cm).

Electron microprobe analyses show a considerable $\mathrm{Ca}$ content in a few natrolites (Table 6). In zeolitic palagonite tuffs from Oahu, natrolite and gonnardite $\left\{\mathrm{Na}_{2} \mathrm{Ca}\right.$ ([Al, Si $\left.\left.]_{5} 0_{10}\right)_{2} 6 \mathrm{H}_{2} \mathrm{O}\right\}$ form an isomorphous solid-solution series (Iijima and Harada, 1968), which may be present in these samples as well.

\section{Albite and K-Feldspar}

Albite and $\mathrm{K}$-feldspar occur only in minor amounts and are restricted to plagioclase. Albite (Table 7) forms irregular patches in large single crystals and phenocrysts in lithic clasts, however, it is rare in plagioclase crystals in shards. K-feldspar (Table 7) was identified in only three samples.

\section{Leucoxene and Sphene}

Leucoxene is a common secondary phase in palagonitic and zeolitized shards, but the two occurrences of
Table 7. Microprobe analyses (wt.\%) of selected secondary minerals: albite (1), K-feldspar (2), apophyllite (3), and gyrolite (4).

\begin{tabular}{lrrrr}
\hline & 1 & \multicolumn{1}{c}{2} & \multicolumn{1}{c}{3} & \multicolumn{1}{c}{4} \\
\hline $\mathrm{SiO}_{2}$ & 67.74 & 65.24 & 51.86 & 54.75 \\
$\mathrm{Al}_{2} \mathrm{O}_{3}$ & 19.26 & 18.07 & 0.09 & 0.87 \\
$\mathrm{Fe}_{2} \mathrm{O}_{3}$ & 0.31 & 0.08 & 0.00 & 0.05 \\
$\mathrm{CaO}^{2}$ & 0.40 & 0.00 & 24.93 & 34.10 \\
$\mathrm{Na}_{2} \mathrm{O}$ & 11.84 & 0.07 & 0.16 & 0.41 \\
$\mathrm{~K}_{2} \mathrm{O}$ & 0.10 & 17.32 & 4.77 & 0.00 \\
Total & 99.65 & 100.78 & 81.82 & 90.18 \\
& & & & \\
$(\mathrm{O}) \mathrm{Basis}$ & 8 & 8 & 20 & 15 \\
$\mathrm{Si}$ & 2.98 & 3.01 & 7.93 & 5.88 \\
$\mathrm{Al}$ & 1.00 & 0.98 & 0.16 & 0.11 \\
$\mathrm{Fe}+$ & 0.01 & 0.00 & 0.00 & 0.00 \\
$\mathrm{Ca}$ & 0.02 & 0.00 & 4.08 & 3.92 \\
$\mathrm{Na}$ & 1.01 & 0.01 & 0.05 & 0.09 \\
$\mathrm{~K}$ & 0.01 & 1.02 & 0.93 & 0.00 \\
$\mathrm{An}$ & 1.8 & & & \\
$\mathrm{Ab}$ & 97.6 & 0.6 & & \\
$\mathrm{Or}$ & 0.6 & 99.4 & & \\
\hline
\end{tabular}

Note: Analysis 1 = albite replacing plagioclase in crystalline basaltic rock fragment $(585-47-2,83-85 \mathrm{~cm}) ; 2$ = K-feldspar, pseudomorph replacement of plagioclase phenocryst in chloritized shard (585-46-3, 142-146 cm); 3 = apophyllite, vesicle filling (585A-19-2, 89-95 cm); 4 = Gyrolite, vesicle filling, partly replaced by apophyllite (585A-19-2, 89-95 cm).

sphene (Samples 585-48-1, 32-36 cm and 585-49-2, 108 $110 \mathrm{~cm}$ ) are restricted to crystalline basaltic fragments. Leucoxene forms spherical crypto- to microcrystalline aggregates-rarely single crystals - with high relief, which vary in size from less than $5 \mu \mathrm{m}$ to $30 \mu \mathrm{m}$. It is translucent in palagonitic, but brown and opaque in zeolitized, shards has undulose extinction, and shows birefringence as high as $n=0.06$. The analysis in Table 8 shows a composition almost identical to sphene as regards $\mathrm{Si}$ and Ti concentrations.

\section{Apophyllite and Gyrolite}

Apophyllite occurs only in Sample 585A-19-2, 89$95 \mathrm{~cm}$, in vesicles, pores, and shards. It postdates chabazite in pores and shards and predates carbonate and sulfate in large vesicles. It is well crystallized, up to $1 \mathrm{~mm}$ in size, and shows a tabular habit $(\| 001)$ with pronounced parallel cleavage and anomalous deep blue to brown interference colors. Apophyllite was identified by both XRD and microprobe analyses (Table 7) in which fluorine was not analyzed.

Internal fibrous textures indicate that apophyllite replaces an earlier fibrous phase, gyrolite, relics of which still exist between subhedral apophyllite crystals. Gyrolite, also identified by XRD and microprobe analyses (Table 7), grows in colorless fibrous to sheave-like aggregates $(<300 \mu \mathrm{m})$ in pores, vesicles, and shards, postdating Ca-analcite. Gyrolite is optically negative and uniaxial, with an anomalous axial angle of $2 V<10$. Its refractive index is about $n=1.53$ and the birefringence reaches $\# n=0.013$. Microprobe analyses gave totals of $90 \mathrm{wt} . \%$ and show minor substitutions of $\mathrm{Al}$ and $\mathrm{Na}$ for $\mathrm{Si}$ and $\mathrm{Ca}$ (Table 7). Experimental data show that gyro- 
lite, a calcium silicate hydrate, is only stable at 140 to $220^{\circ} \mathrm{C}$ (Speakman, 1968). It is a common late vein and vesicle-filling phase in the laumontite-prehnite-quartzchlorite metamorphic zone in the Deccan Traps, where it also predates apophyllite (Sukheswala et al., 1974).

\section{Carbonate}

Secondary Ca-carbonate occurs in trace amounts as a cementing phase and also replaces olivine and plagioclase. It is always preceded by all other secondary phases except natrolite, with which it may be intimately intergrown in former olivine $(585-48-1,32-36 \mathrm{~cm})$. In olivine, plagioclase, or vesicles, where it is surrounded by fibrous aggregates of chlorite/smectite m.m., it fills central cavities as homoaxial $(<0.6 \mathrm{~mm})$, or mosaics as hypidiomorphic, crystals. It forms mosaic aggregates of irregularly shaped crystals less than $100 \mu \mathrm{m}$ in size, as a poikilitic cementing phase.

\section{Sulfate}

Ca-sulfate was found only near the base of the section (Sample 585A-19-2, 89-95 cm). It was crystallized in vesicles after apophyllite, but predates calcite in central portions of vesicles larger than $5 \mathrm{~mm}$ in diameter.

\section{Alteration Sites}

Four different sites of alteration, characterized by different secondary mineral assemblages, were distinguished: shards, crystals, vesicles, and pore spaces.

\section{Shard Alteration}

In most samples, several stages in the alteration of formerly vitric shards were recognized. Exceptions are some of the uppermost samples (e.g., 585-42-3, 30-34 $\mathrm{cm}$ ), where the fine-grained (about $100 \mu \mathrm{m}$ ) thin-walled shards (bubble-wall type) are completely altered to microcrystalline pale yellowish smectite/illite. In these samples, shard structures are poorly preserved, and distinction between shards and former pore space, cemented with smectite/illite, is often impossible.

The coarser-grained vitric tuffs show several stages and/or types of shard alteration. We distinguish the following: (1) palagonitization; (2) zeolitic replacement of palagonite; and-subsequently or earlier-(3) dissolution of glass and/or palagonite, with subsequent cementation of dissolution pores.

1. Palagonitization is here used as a descriptive term for various kinds of cryptocrystalline (or even amorphus?)-rarely microcrystalline-brown-yellowish brown products of shard alteration. Electron microprobe analyses of palagonite-even of "fresh"-looking parts of palagonitized shards (light brown-yellowish, isotropic, no microgranular texture)-yield totals as low as $68 \%$ (Table 4), indicating high water contents. The larger amount of loosely adsorbed water within the palagonite is also reflected in the widespread occurrence of shrinkage cracks within and around the shards (Plates 1, 2, 5).

Alteration banding, usually characteristic of palagonitization, is not common but is nevertheless present, especially in samples of the upper sequence. Palagonitized shards may be isotropic to weakly or moderately birefringent. The generally undulose extinction is interpreted as resulting from slightly ordered arrangement of the cryptocrystalline phases, probably smectite for the most part, as suggested by optical appearance and chemical composition (Table 4). Translucent to opaque, highly refractive spherical leucoxene aggregates-rarely single crystals-occur within the palagonite. They are irregularly dispersed or are concentrated along contours of vesicles and shards or like strings of pearls within the shards. Most shards are homogeneously palagonitized, but central or marginal areas are commonly slightly darker (Plate 1, Fig. 2) or even opaque (Plate 2, Fig. 1) and generally less birefringent or isotropic. These zones are characterized chemically by higher $\mathrm{TiO}_{2}$ and $\mathrm{CaO}$ contents, and in part by higher $\mathrm{FeO}$ as well.

Electron microprobe analyses of optically inhomogeneous palagonitic shards show relatively continuous transition from Ti-poor smectite to Ti-rich "leucoxenic palagonite" (Table 4, Fig. 7), which is roughly correlated with increasingly darker colors of the palagonite. Leucoxene spherules are compositionally close to sphene, the more "mature" alteration product. Ti-rich palagonite and leucoxene of Sample 585-49-2, 108-110 cm (Table 8 ) almost resemble sphene composition with respect to $\mathrm{Ti}$ and $\mathrm{Si}$ concentrations, but interestingly show a deficiency in $\mathrm{Ca}$, perhaps owing to the simultaneous growth of chabazite.

2. The next alteration step is the replacement of palagonite by analcite and/or chabazite. Two types of zeolitization were recognized. One type, most common in the lower sequence, is characterized by analcite, replacing shards from the outside inward (Plate 3, Fig. 1). Analcite is either clear or inclusion-rich, inclusions being either "dusty" or aggregates of leucoxene. Crystal morphology of analcite is not well developed, but several individua can be distinguished in the shard rim. The second type, more common in the upper sequence of Unit VI, can best be characterized as isomorphic replacement of palagonite, with no crystal faces visible in the shard. This zeolite is mostly pale yellowish, presumably because of submicroscopic inclusions. Transitions to palagonite are gradual (slight color change within some micrometers distance), whereas boundaries toward chlorite and/or chlorite/smectite-filled vesicles are extremely sharp. Most commonly, outer shard areas are first replaced by "isomorphic zeolite," but central parts are affected by this type of alteration as well (Plate 5). Some shards are completely replaced by isomorphic analcite which is generally completely isotropic, and are thus easily mistaken at first sight for fresh silicic glass, especially if they are highly vesicular (Plate 1, Fig. 1).

3 . During any of the described alteration stages, complete or partial dissolution of either the remaining glass or its alteration product may occur, the pore space created being subsequently filled by different phases, most commonly by chabazite and analcite, rarely by natrolite, or, exceptionally, by calcite.

One example of complex alteration within one shard is shown in Figure 10 and Plate 4. Alteration of this shard passed through palagonitization (relict palagonitic areas still are present) with subsequent or simultane- 
Table 8. Microprobe analyses (wt.\%) along profile across altered shard (see Fig. 10).

\begin{tabular}{|c|c|c|c|c|c|c|c|c|c|c|c|c|}
\hline & 1 & 2 & 3 & 4 & 5 & 6 & 7 & 8 & 9 & 10 & 11 & 12 \\
\hline $\mathrm{SiO}_{2}$ & 53.60 & 32.54 & 28.53 & 60.67 & 59.64 & 31.69 & 55.99 & 38.99 & 30.38 & 27.60 & 54.56 & 54.47 \\
\hline $\mathrm{TiO}_{2}$ & 3.58 & 0.27 & 13.89 & 0.22 & 0.42 & 33.85 & 0.31 & 1.97 & 6.33 & 19.70 & 2.86 & 1.67 \\
\hline $\mathrm{Al}_{2} \mathrm{O}_{3}$ & 18.85 & 8.91 & 5.12 & 17.15 & 16.96 & 2.78 & 17.84 & 9.26 & 6.56 & 4.24 & 19.03 & 19.81 \\
\hline $\mathrm{Cr}_{2} \mathrm{O}_{3}$ & - & 0.02 & 0.08 & - & 0.01 & 0.11 & 0.03 & 0.10 & 0.02 & 0.11 & - & 0.03 \\
\hline $\mathrm{FeO}$ & 0.66 & 11.16 & 7.76 & 0.15 & 0.12 & 6.76 & 0.26 & 14.90 & 10.69 & 5.64 & 0.98 & 0.54 \\
\hline $\mathrm{MnO}$ & 0.06 & 0.17 & 0.09 & 0.02 & 0.02 & 0.43 & - & 0.10 & 0.12 & 0.18 & 0.04 & - \\
\hline $\mathrm{MgO}$ & 0.08 & 9.97 & 4.46 & 0.03 & 0.02 & 0.32 & - & 10.89 & 8.38 & 1.24 & 0.16 & 0.25 \\
\hline $\mathrm{CaO}$ & 1.07 & 2.94 & 3.70 & 5.71 & 5.76 & 8.20 & 5.61 & 2.59 & 2.88 & 4.94 & 0.71 & 0.66 \\
\hline $\mathrm{Na}_{2} \mathrm{O}$ & 11.69 & 0.88 & 0.94 & 5.26 & 5.34 & 1.24 & 5.05 & 2.11 & 1.37 & 0.69 & 10.51 & 11.63 \\
\hline $\mathrm{K}_{2} \mathrm{O}$ & 0.05 & 0.13 & 0.30 & 0.13 & 0.10 & 1.44 & 0.12 & 0.25 & 0.18 & 0.18 & 0.05 & 0.01 \\
\hline Total & 89.64 & 66.99 & 64.87 & 89.34 & 88.37 & 86.82 & 85.21 & 81.16 & 66.90 & 64.52 & 88.54 & 89.06 \\
\hline
\end{tabular}

Note: All iron calculated as $\mathrm{Fe}^{2+}$. Dash indicates concentration below detection limit.

ous formation of areas enriched in $\mathrm{Fe}, \mathrm{Ti}$, and $\mathrm{Mg}$. The chronological order of the ensuing alteration steps is not clear. Marginal isomorphic replacement of palagonite by analcite may have been followed by stepwise dissolution of central (still glassy or palagonitic?) areas and cementation with chabazite, whereby, immobile elements which did not fit into the structure of the zeolite were concentrated in aggregates of leucoxene. A chemical profile across the shard, compared with fresh glass from the same layer, shows some of the elemental changes and the sites where some elements are enriched and others depleted (Fig. 10).

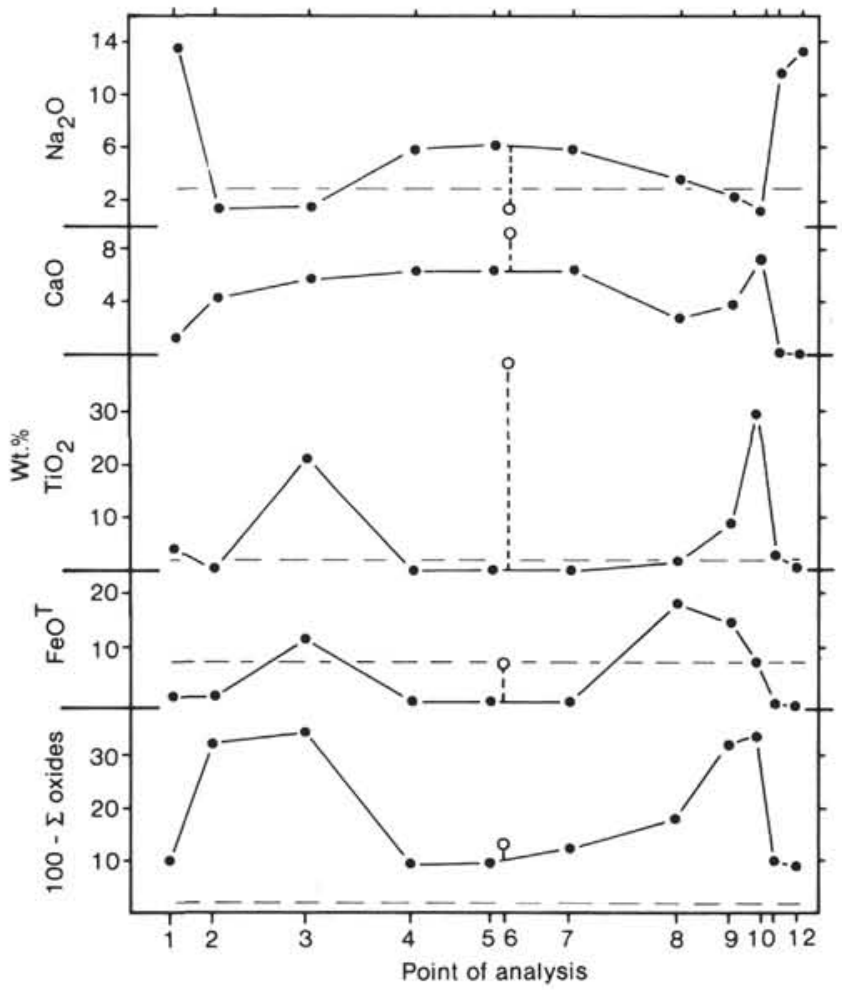

Figure 10. Variation of oxides along profile across altered glass shard in Sample 585-49-2, 108-110 cm (Table 8; Plate 4, Figs. 1 and 2). Dotted lines: reference values of fresh glass shard in 585-49-2, 90$94 \mathrm{~cm}$. Note replacement by chabazite with isolated spheres of leucoxene in the central plain, and by analcite along the rim.

\section{Alteration of Crystals}

\section{Plagioclase}

Altered plagioclase, not analyzed extensively, is strongly to completely altered in the upper sequence. Plagioclase phenocrysts, common in shards in the lower sequence, are less strongly altered than microlites, which are always replaced by an intergrowth of dominantly fibrous chlorite/smectite m.m. and K-feldspar. Large single crystals and phenocrysts in lithic clasts show irregular patchy albitization. The most strongly albitized plagioclase crystals are dusty, and in two cases form crystal aggregates with primary pyroxene and secondary chlorite and sphene. The high degree of alteration, in association with the latter minerals, may indicate alteration of these clasts before redeposition.

In the turbiditic sequence (samples from Hole 585, Cores 55-42), plagioclase was mostly replaced by analcite or any combination of the minerals chlorite/smectite m.m., calcite, and natrolite. The sheet silicates form a closed or open, irregularly-shaped rim inside the feldspar, the rest of the crystal being filled by a mosaic of either of the other two phases.

\section{Olivine}

Olivine is everywhere completely altered. Microphenocrysts in shards, as well as those in tachylitic and crystalline basaltic clasts, are generally replaced by coarse fibrous aggregates of chlorite/smectite m.m. Larger crystals show two distinct types of complete replacement: (1) by analcite only (Plate 3, Fig. 2) and (2) by chlorite/ smectite m.m. aggregates lining crystal faces and fractures, locally grading into chlorite (Plate 2, Fig. 1). These sheet silicates in part surround a second alteration phasecalcite or a zeolite-which completely fills the central portion of a crystal. The similarity in replacement sequence and texture in olivine-and some plagioclaseand vesicles suggests at least partial dissolution of the primary mineral phases or secondary phases before calcite or zeolite crystallization.

\section{Vesicles}

Vesicles exhibit a characteristic mineralization sequence, commonly starting with a very thin "coating" $(<4 \mu \mathrm{m})$ of cryptocrystalline smectite, followed inward 
by brown-green to opaque fibrous, radial aggregates of chlorite/smectite m.m. (10-130 $\mu$ m; Plate 1, Fig 1; Plate 2; Plate 3, Fig. 2). Vesicles larger than about $70 \mu \mathrm{m}$ are dominantly filled by chabazite. If the shards are completely replaced by analcite, this sequence is either lightercolored, with lower relief, pleochroism, birefringence, and oxide coating, or has been reduced to a thin $(10-\mu \mathrm{m})$ cryptocrystalline to fibrous chlorite/smectite lining.

\section{WHOLE-ROCK CHEMISTRY}

Ten volcaniclastic rocks distributed over most of the section were analyzed for major and trace elements (Tables 9 and 10). The rocks contain from 4 to $7.5 \mathrm{wt} . \%$ $\mathrm{H}_{2} \mathrm{O}{ }^{+}$and from 0.5 to 4.8 wt. $\% \mathrm{CO}_{2}$, indicating both advanced degrees of diagenetic alteration (especially formation of sheet silicates and zeolites by replacement of glass and crystallization from pore solutions) and admixture of calcareous organic debris. Other evidence of alteration is the high degree of oxidation $\left(\mathrm{Fe}_{2} \mathrm{O}_{3} / \mathrm{FeO}\right.$ ranging from 1.5 to 3 ), a general loss of $\mathrm{Ca}$, and, in Hole 585A, addition of Na. The enriched patterns of $\mathrm{Rb}$ and some of the erratic $\mathrm{Sr}$ concentrations are also due to alteration, and the latter result also from admixture of biogenic clasts. Most of the other element concentrations have also been influenced by alteration, but on the whole alteration is surprisingly minor. Such changes are difficult to quantify, but are evident when elemental concentrations are viewed as a whole. Two points are emphasized:

1. The analyses clearly reflect the basaltic compositions of all rocks analyzed (Figs. 11, 12), thus confirming the petrographic observations. Moreover, all rocks are relatively mafic, as also reflected by appreciable $\mathrm{Cr}$ contents in pyroxenes. $\mathrm{Mg}$ values range from 67 to 57 , but must be treated with caution because of the mobility of $\mathrm{Mg}$. Nevertheless, the concentrations of the compatible elements $\mathrm{Cr}, \mathrm{Co}$, and $\mathrm{Ni}$ all confirm the major-element data; the more mafic basalts of Hole 585, with higher $\mathrm{Mg}$ values, also show higher concentrations of compatible trace elements.

2. The analyses fall into two major groups that also differ stratigraphically (Figs. 12, 13). Most rocks from the lower sequence show significantly lower concentrations of incompatible elements $(\mathrm{Ba}, \mathrm{Nb}, \mathrm{Zr}, \mathrm{Y}, \mathrm{Sr}, \mathrm{Rb}$, $\mathrm{P}, \mathrm{K}$ ), as well as lower concentrations of $\mathrm{Ti}$, than those from the upper sequence. We will discuss these two
Table 10. Trace-element analyses (ppm) of whole rock samples.

\begin{tabular}{lcccrrrrrrrr}
\hline $\begin{array}{c}\text { Sample } \\
\text { (interval in cm) }\end{array}$ & $\mathrm{Cr}$ & $\mathrm{Co}$ & $\mathrm{Ni}$ & $\mathrm{Cu}$ & $\mathrm{Zn}$ & $\mathrm{Rb}$ & $\mathrm{Sr}$ & $\mathrm{Y}$ & $\mathrm{Zr}$ & $\mathrm{Nb}$ & $\mathrm{Ba}$ \\
\hline $585-43-3,30-34$ & 450 & 37 & 166 & 96 & 98 & 27 & 353 & 20 & 175 & 38 & 210 \\
$585-43-2,140-144$ & 333 & 45 & 115 & 111 & 138 & 29 & 338 & 22 & 195 & 45 & 296 \\
$585-47-2,83-85$ & 300 & 38 & 128 & 57 & 91 & 19 & 553 & 20 & 159 & 35 & 168 \\
$585-49-2,112-119$ & 382 & 53 & 222 & 158 & 115 & 28 & 265 & 21 & 190 & 41 & 172 \\
$585-54-1,57-59$ & 495 & 48 & 246 & 90 & 109 & 23 & 94 & 22 & 190 & 45 & 183 \\
$585-55-2,78-82$ & 569 & 53 & 307 & 77 & 104 & 20 & 185 & 20 & 174 & 42 & 187 \\
$585 \mathrm{~A}-16, \mathrm{CC}$ & 276 & 27 & 104 & 52 & 80 & 17 & 91 & 16 & 92 & 13 & 79 \\
$585 \mathrm{~A}-17-1,11-14$ & 290 & 29 & 126 & 51 & 81 & 14 & 352 & 18 & 84 & 12 & 77 \\
$585 \mathrm{~A}-17-3,138-141$ & 284 & 30 & 116 & 52 & 75 & 19 & 87 & 17 & 89 & 13 & 46 \\
$585 \mathrm{~A}-18-2,72-75$ & 293 & 29 & 136 & 70 & 76 & 19 & 104 & 18 & 86 & 14 & 64 \\
\hline
\end{tabular}

Note: Analyses done by X-ray fluorescence.

groups, which for simplicity we call tholeiites (lower) and alkalic basalts (upper group), at the end of this chapter.

\section{GLASS COMPOSITIONS}

Whole-rock compositions of submarine lavas, and especially of volcaniclastic rocks, are always difficult to interpret when rocks are altered. Fortunately, fresh glass inclusions were found in clinopyroxene and plagioclase phenocrysts in four samples and one reasonably fresh glass shard was found in Sample 585-49-2, 90-94 cm (Table 11, Fig. 11). The interpretation of such glasses is not straightforward, however. The glass shard may have become chemically modified during diagenesis. Glass inclusions are generally less mafic than the whole rocks.

\section{Glass Inclusions}

In the lower tholeiitic rock group, the glass inclusion is less mafic than the whole rock, as shown by higher $\mathrm{K}_{2} \mathrm{O}, \mathrm{SiO}_{2}$, and $\mathrm{FeO}$ concentrations. The significantly lower $\mathrm{Na}$ and higher $\mathrm{Ca}$ concentrations in the inclusion are interpreted as reflecting $\mathrm{Ca}$ loss and $\mathrm{Na}$ gain by the whole rock during alteration. The lower $\mathrm{Al}$ values are interpreted as reflecting plagioclase crystallization.

The analyses of glass inclusions in clinopyroxenes from three different rocks of the alkali basaltic upper sequence are more tightly grouped than those of the whole rocks. Concentrations are broadly similar in $\mathrm{K}_{2} \mathrm{O}, \mathrm{Na}_{2} \mathrm{O}$, and $\mathrm{FeO}$ concentrations. The most striking differences, as in the tholeiitic group, are higher $\mathrm{Ca}$ content and, less pronounced, the generally lower $\mathrm{Mg}$ content. $\mathrm{Al}$ appears to have been lost and $\mathrm{Si}$ added from several whole rocks, compared with the glass inclusions.

Table 9. Major-element compositions (wt.\%) of whole rock samples.

\begin{tabular}{|c|c|c|c|c|c|c|c|c|c|c|c|c|c|c|}
\hline $\begin{array}{c}\text { Sample } \\
\text { (interval in } \mathrm{cm} \text { ) }\end{array}$ & $\mathrm{SiO}_{2}$ & $\mathrm{TiO}_{2}$ & $\mathrm{Al}_{2} \mathrm{O}_{3}$ & $\mathrm{Fe}_{2} \mathrm{O}_{3}$ & $\mathrm{FeO}$ & $\mathrm{MnO}$ & $\mathrm{MgO}$ & $\mathrm{CaO}$ & $\mathrm{Na}_{2} \mathrm{O}$ & $\mathrm{K}_{2} \mathrm{O}$ & $\mathrm{P}_{2} \mathrm{O}_{5}$ & $\mathrm{H}_{2} \mathrm{O}$ & $\mathrm{CO}_{2}$ & Totals \\
\hline $585-42-3,30-34$ & 52.30 & 2.36 & 11.64 & 6.80 & 2.27 & 0.19 & 8.68 & 5.47 & 1.92 & 0.96 & 0.29 & 5.75 & 1.20 & 99.83 \\
\hline $585-43-2,140-144$ & 50.20 & 3.20 & 11.58 & 9.08 & 2.92 & 0.19 & 7.31 & 6.83 & 2.06 & 1.06 & 0.32 & 4.09 & 0.55 & 99.39 \\
\hline $585-47-2,83-85$ & 43.80 & 2.68 & 13.20 & 7.27 & 3.12 & 0.16 & 9.42 & 6.56 & 4.52 & 0.35 & 0.37 & 7.01 & 2.04 & 100.5 \\
\hline $585-49-2,112-117$ & 48.20 & 2.74 & 13.12 & 7.16 & 3.13 & 0.12 & 6.26 & 5.80 & 2.81 & 0.86 & 0.31 & 7.62 & 1.09 & 99.22 \\
\hline $585-54-1,57-59$ & 42.40 & 2.65 & 11.74 & 6.32 & 4.62 & 0.19 & 9.57 & 9.35 & 3.58 & 0.93 & 0.42 & 4.95 & 2.03 & 98.72 \\
\hline $585-55-2,78-82$ & 42.90 & 2.50 & 12.03 & 6.97 & 4.46 & 0.18 & 10.58 & 8.88 & 3.30 & 0.40 & 0.35 & 5.94 & 1.47 & 99.96 \\
\hline $585 \mathrm{~A}-16, \mathrm{CC}$ & 44.80 & 1.64 & 13.18 & 6.44 & 2.39 & 0.14 & 6.34 & 8.63 & 5.86 & 0.23 & 0.21 & 6.26 & 3.17 & 99.29 \\
\hline $585 \mathrm{~A}-17-1,11-14$ & 43.30 & 1.59 & 12.63 & 6.53 & 2.19 & 0.14 & 6.53 & 10.35 & 4.68 & 0.21 & 0.20 & 6.82 & 4.05 & 99.42 \\
\hline $585 \mathrm{~A}-17-3,138-141$ & 44.00 & 1.61 & 12.69 & 6.26 & 2.67 & 0.14 & 6.55 & 9.84 & 5.73 & 0.19 & 0.20 & 6.05 & 4.17 & 100.10 \\
\hline $585 \mathrm{~A}-18-2,72-75$ & 42.30 & 1.55 & 12.05 & 6.44 & 2.38 & 0.13 & 6.86 & 10.85 & 5.21 & 0.17 & 0.20 & 5.85 & 4.84 & 98.83 \\
\hline
\end{tabular}

Note: Analyses done by X-ray fluorescence, except analyses for $\mathrm{FeO}, \mathrm{H}_{2} \mathrm{O}$, and $\mathrm{CO}_{2}$, done by classical techniques. 


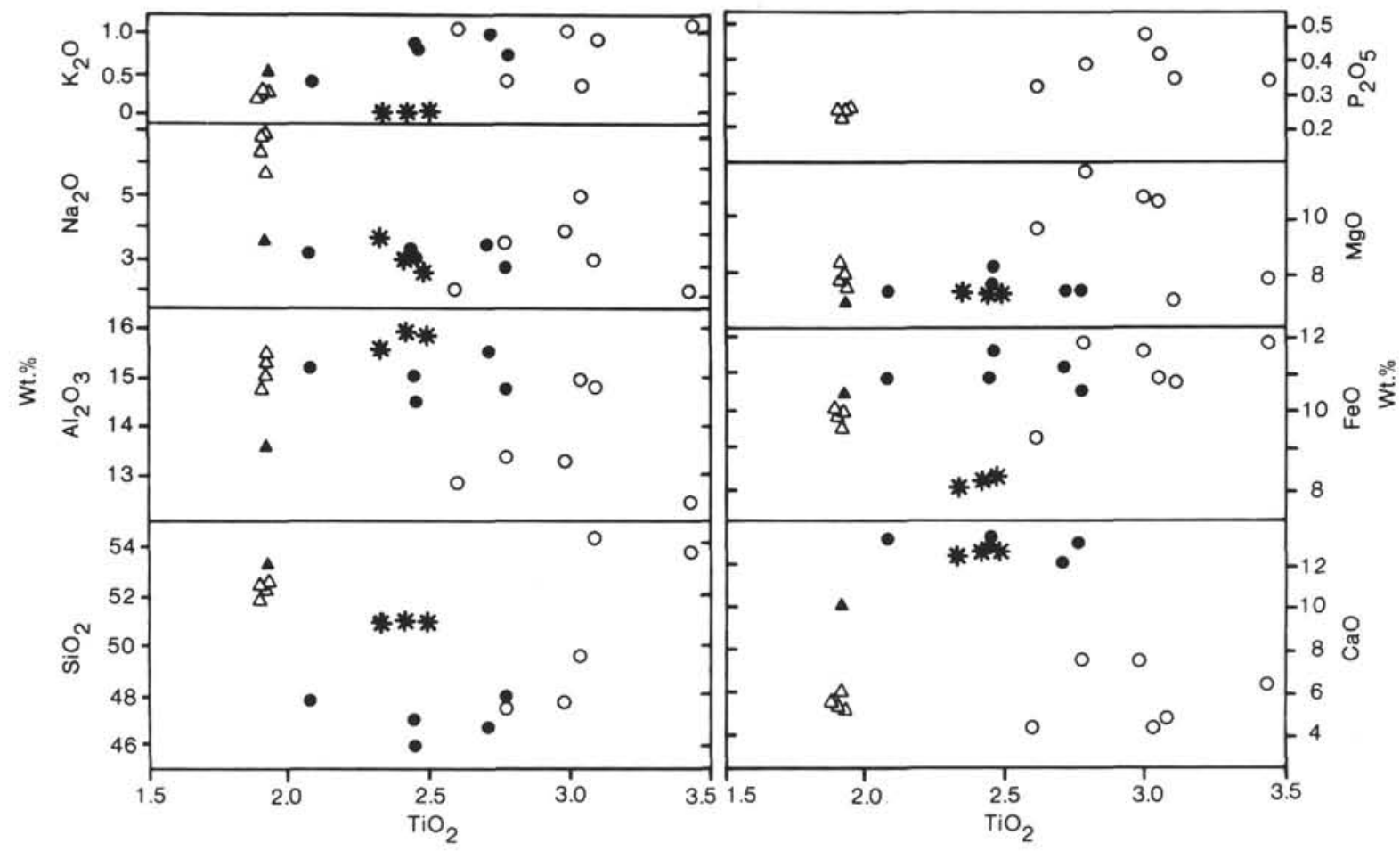

Wt.\%

Figure 11. $\mathrm{TiO}_{2}$-variation diagram of major elements of whole rocks (volcaniclastic sediments, open symbols, XRF). Glass inclusions (closed symbols, electron microprobe) and fresh glass shard (stars, electron microprobe) are shown for comparison. Circles and dots: samples from Cores 43 to 55, Hole 585. Filled and open triangles: samples from Cores 16 to 19, Hole 585A.

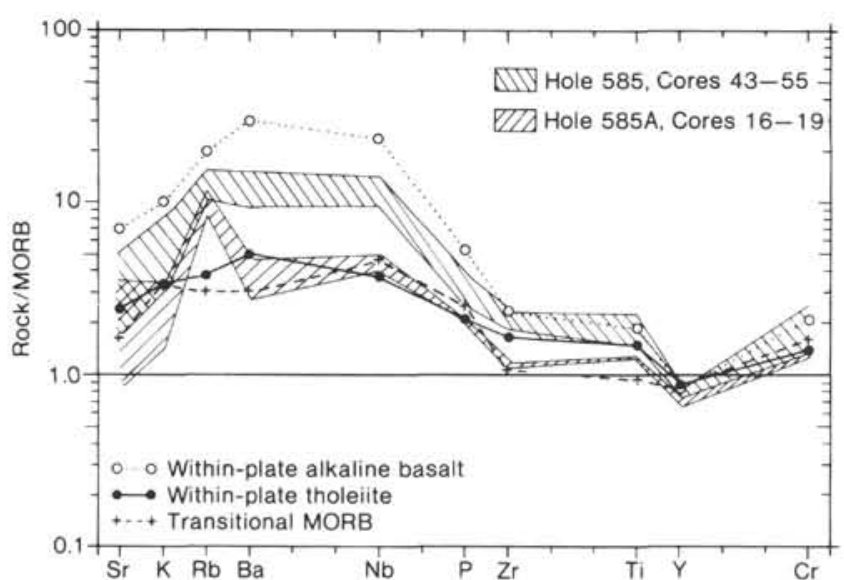

Figure 12. MORB-normalized incompatible-element patterns for wholerock samples (XRF) and glass inclusions (microprobe) in Unit VI, Site 585 (for normalizing values, see Pearce, 1982). Variation of samples from upper sequence (Hole 585, Cores 43-55) includes 6 whole rocks and 5 glass inclusions $(\mathrm{K}$ and $\mathrm{Ti}$ only); samples from lower sequence (Hole 585A, Cores 16-19) include 4 whole rocks and 1 glass inclusion.

\section{Glass Shard in Alkali Basalt}

The alteration changes are also shown by the composition of the glass shard, which similarly differs from the whole rock. Other differences between glass shard and whole rock cannot be interpreted with certainty. The lower $\mathrm{K}$ and $\mathrm{Si}$ concentrations are certainly more closely related to the original magma (the extremely low $\mathrm{K}_{2} \mathrm{O}$ values of about zero are analytically correct) than those in whole-rock analyses. The similarity in $\mathrm{MgO}$ content between shard and glass inclusion suggests Mg-uptake by the whole rock (smectite). Low Fe and high $\mathrm{Al}$ concentrations in the shard are difficult to interpret.

\section{DISCUSSION}

\section{Primary Magma Composition}

The volcaniclastic rocks consist of components derived from different sources. Despite some admixture of epiclastic fragments and biogenic and oolitic debris, and despite pervasive alteration, the chemical analyses of bulk rocks reflect those of magmas to a surprising degree. Comparison of whole rocks and glasses shows that whole rocks have lost roughly 30 to $50 \%$ of their calcium, have gained some portion (alkali basalts) to $100 \%$ (tholeiites) of their sodium and up to about $30 \%$ of their Mg. Other changes are most complex. The more surprising result regarding alteration is the lack of major K-addition in the volcaniclastic rocks, reflected mineralogically by the complete replacement of phillipsite as a secondary mineral.

The parent magmas of all rocks were mafic basalt magmas. This is also shown by the phenocrysts clinopyroxene (fresh), spinel (fresh), olivine (replaced), and plagioclase (partly replaced). The lower sequence of the volcaniclastic section (Hole 585A, Section 16,CC to Core 19 , below about $830 \mathrm{~m}$ ) is tholeiitic, as shown by (1) low concentrations of incompatible trace elements, as well 


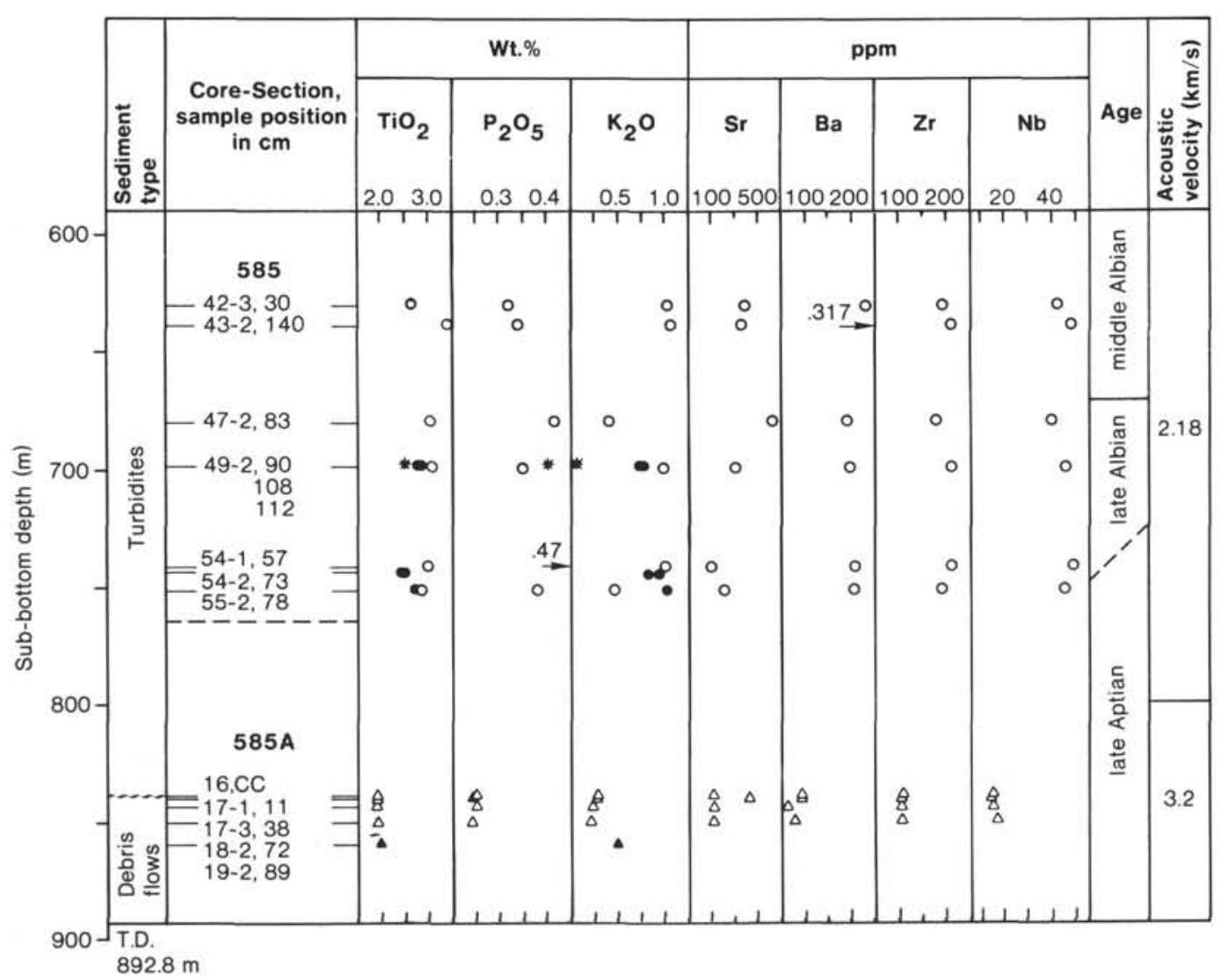

Figure 13. Selected major and trace elements versus stratigraphy in samples from Unit VI (same symbols as in Fig. 11). Note distinctly higher concentrations of incompatible elements in samples from upper alkali basaltic section.

Table 11. Microprobe analyses (wt. \%) of glass shard (585-49-2, 90-92 $\mathrm{cm})$, glass inclusions in pyroxenes $(585-49-2,108-110 \mathrm{~cm}$ to $585-55-2,78-82 \mathrm{~cm})$ and in plagioclase $(585 \mathrm{~A}-19-2,108-110 \mathrm{~cm})$.

\begin{tabular}{lccccccccc}
\hline $\begin{array}{c}\text { Sample } \\
\text { (interval in cm) }\end{array}$ & $\mathrm{SiO}_{2}$ & $\mathrm{TiO}_{2}$ & $\mathrm{Al}_{2} \mathrm{O}_{3}$ & $\mathrm{FeO}$ & $\mathrm{MgO}$ & $\mathrm{CaO}$ & $\mathrm{Na}_{2} \mathrm{O}$ & $\mathrm{K}_{2} \mathrm{O}$ & Total \\
\hline $\mathbf{5 8 5 - 4 9 - 2 , 9 0 - 9 2}$ & 49.6 & 2.43 & 15.42 & 8.1 & 7.1 & 12.3 & 2.6 & 0.0 & 97.55 \\
$\mathbf{5 8 5 - 4 9 - 2 , 9 0 - 9 2}$ & 50.2 & 2.30 & 15.35 & 7.9 & 7.2 & 12.1 & 3.7 & 0.0 & 98.75 \\
$\mathbf{5 8 5 - 4 9 - 2 , 9 0 - 9 2}$ & 49.8 & 2.36 & 15.57 & 8.0 & 7.0 & 12.1 & 2.9 & 0.0 & 97.73 \\
$585-49-2,108-110$ & 46.7 & 2.69 & 14.37 & 10.2 & 7.2 & 12.7 & 2.8 & 0.7 & 97.36 \\
$\mathbf{5 8 5 - 5 4 - 2 , 7 3 - 7 5}$ & 45.8 & 2.38 & 14.62 & 10.5 & 7.4 & 12.5 & 3.2 & 0.9 & 97.30 \\
$585-54-2,73-75$ & 44.6 & 2.38 & 14.06 & 11.3 & 8.0 & 12.8 & 3.2 & 0.8 & 97.14 \\
$585-54-2,73-75$ & 46.5 & 2.02 & 14.80 & 10.7 & 7.1 & 12.7 & 3.1 & 0.4 & 97.32 \\
$585-55-2,78-82$ & 45.2 & 2.62 & 15.03 & 10.7 & 7.1 & 11.7 & 3.4 & 1.0 & 96.75 \\
$585 \mathrm{~A}-19-2,108-111$ & 52.0 & 1.88 & 13.22 & 10.1 & 6.7 & 9.8 & 3.4 & 0.5 & 97.60 \\
\hline
\end{tabular}

Note: All iron measured as FeO.

as $\mathrm{K}, \mathrm{P}$, and $\mathrm{Ti}$; (2) a phenocrysts assemblage in which olivine and plagioclase dominate in amount and size over clinopyroxene; and (3) low $\mathrm{Ti}-, \mathrm{Ca}-$, and $\mathrm{Al}$-clinopyroxene and the occurrence of pigeonite. Also, the vesicularity of formerly glassy shards is less than in the upper sequence. A comparison of selected incompatible-element contents with published data on Cretaceous basalts from previous DSDP Legs (Leg 17: Bass et al., 1973; Leg 30: Stoeser, 1975; Leg 33: Jackson et al., 1976; Leg 61: Shcheka, 1981), in diagrams commonly used for presentation of chemical data in these reports $\mathrm{Zr}$ vs. $\mathrm{Nb}, \mathrm{Ba}$, or $\mathrm{Sr} ; \mathrm{P}_{2} \mathrm{O}_{5}$ vs. $\mathrm{TiO}_{2}$ ), indicates a MORB origin for the tholeiitic samples studied, comparable to rocks from Ontong-Java Plateau, Hole 289, and Nauru Basin,
Hole 462, which are also lower to middle Cretaceous. Chromites are titaniferous, however, throughout the entire section, which is characteristic of tholeiites from ocean islands (OIT) rather than a MORB environment. The fact that compositions of tholeiitic to alkalic basalts dredged from the top of Loihi Seamount (Frey and Clague, 1983) also fall into the field for rocks of MORB origin in these diagrams shows their restricted value for classifying basalts. By comparison with these ocean-island tholeiites (Frey and Clague, 1983) and E- and NMORB samples drilled during Leg 82 in the North Atlantic (Sachtleben et al., in press), tholeiitic rocks from Hole 585A show the following characteristics:

1. Relatively high $\mathrm{P}_{2} \mathrm{O}_{5}, \mathrm{Nb}$, and $\mathrm{Ba}$ contents resemble those of E-MORB or ocean-island tholeiites.

2. Somewhat higher $\mathrm{Ti} / \mathrm{Zr}$ ratios show their tendency toward ocean-island tholeiites, as do $\mathrm{Cr}$ and $\mathrm{Ni}$ values distinctly smaller than those from average transitional or enriched MORB-tholeiites (Pearce, 1982).

3. Low $\mathrm{Sr}$ and $\mathrm{K}_{2} \mathrm{O}$ concentrations (about $100 \mathrm{ppm}$ and $0.2 \mathrm{wt} . \%$, respectively), similar to MORB, are probably due to alteration effects (see "Alteration," following).

The upper alkali-basaltic rocks are richer in incompatible elements and slightly more mafic. Clinopyroxene, some approaching titanaugite in composition, is the dominant phenocryst phase, followed by olivine and minor plagioclase. These rocks are similar in incompati- 
ble-element composition to the mildly alkalic basalts drilled during Leg 20, Holes 170 and 171 (on Horizon Guyot; Bass et al., 1973) and Leg 33 in Hole 315A near Fanning Island in the central Pacific (Jackson et al., 1976).

\section{Clastic Processes}

All volcaniclastic material studied was deposited by submarine mass flows. A lower sequence of debris flows, below Sample 585A-16,CC, can be distinguished from an upper turbidite sequence. Interestingly, this contrast in depositional mode also corresponds to the many compositional and textural differences already discussed. The number of samples we studied is far too small to attempt, first, any explanation of why this correlation exists, or, second, to locate the exact position (which must be between Core 55 of Hole 585 and Core 16 of Hole $585 \mathrm{~A}$ ) where the rock type changes from tholeiitic to mildly alkalic.

Thick sequences of volcaniclastic rocks in ocean basins are most commonly derived from ocean islands, island arcs, or volcanically active continental margins, and are often moderately to highly differentiated in composition. A significant aspect of the 300 -m-thick volcaniclastic sequence (Unit VI) drilled at Site 585 is the uniform basaltic composition. Moreover, textural evidence of the lower sequence does not indicate any subaerial explosive volcanic activity. Some cuneiform wedge-shaped shards suggest spalling of glassy rinds of lava flow tops or pillow rinds, and tachylitic variolitic clasts suggest some breakage subsequent to cooling. The paucity of vesicular tachylitic and clearly epiclastic crystalline basalt fragments, and the preponderance of mostly unbroken ooids over skeletal fragments in the lower sequence, suggest a low-energy shallow-water environment. Emergence of a volcanic edifice above water is indicated by the volcanic epiclasts. Clastic processes reflected in the clast type of the lower sequence and the morphology of shards thus include spalling, subaerial and submarine erosion, and possibly granulation caused by both thermal shock and mechanical attrition during submarine extrusion of lava.

Shards (now replaced) of the upper sequence, in contrast, are predominantly highly vesicular formerly glassy shards and tachylite. Moreover, crystalline basalt epiclasts are relatively abundant, and rare mugearite clasts are present. The dominant calcareous clasts change from ooids to skeletal debris of shallow-water organisms. Although the increase in vesicularity of formerly glassy shards could largely reflect decreasing confining pressure (water depth), it could also reflect higher volatile-component partial pressures associated with a change in magma composition. Calcareous clasts, whether ooids or skeletal debris, uniformly indicate, throughout the entire volcaniclastic section (Unit VI), a shallow-water environment (less than $300 \mathrm{~m}$ depth?) at the sources of the volcaniclastic sediments, suggesting that major differences in water depth were not very important. Also, a subaerial edifice had clearly grown this time, indicated by vesicular tachylite, oxidized olivine phenocrysts, and well-rounded crystalline basalt clasts.

\section{Alteration}

The twofold subdivision of the entire volcaniclastic section of Unit VI, based on primary composition and clastic and depositional processes, is not reflected in the assemblages of secondary minerals or in the alteration pattern. Because most of the samples are former vitric tuffs, diagenetic changes are characterized by glass shard alteration. Thus, the main alteration phase is palagonite, which often shows considerable $\mathrm{TiO}_{2}$ concentrations.

Among the zeolites, analcite is the most abundant phase, dominating over chabazite and minor natrolite. No phillipsite was found, but it can be assumed to have been present as an early alteration product because of the abundance of relict structures in analcitic portions of the samples. This predominance of analcite is not unexpected, because phillipsite appears to be restricted to marine sediments younger than mid-Cretaceous or the upper $500 \mathrm{~m}$ of younger sediments (Kastner, 1981). However, we have previously noted the surprising lack of $\mathrm{K}$ enrichment in the ten whole rocks analyzed. Strong Kenrichment, which is generally thought to be due to seawater-rock interactions (e.g., Honnorez, 1981; Kastner, 1981; Staudigel and Hart, 1983; Fisher and Schmincke, 1984), may have been prevented by rapid sedimentation. We do not know the primary $\mathrm{K}_{2} \mathrm{O}$ concentrations of the tholeiites of the lower sequence of Unit VI, but have argued here that they resemble ocean-island tholeiites more than MORB. Thus, primary $\mathrm{K}_{2} \mathrm{O}$ concentrations of between 0.3 and 0.5 wt. $\%$ are expected.

We assume, therefore, supported by textural evidence, that the K-rich phases such as phillipsite had originally formed during early alteration, but only in small amounts, and became unstable with time and increasing depth of burial and temperature. Minor amounts of K, among other elements, must have been expelled from the volcaniclastic sediments during later diagenesis. They may have been transported by upward-migrating solutions to the overlying sediments (dominantly claystones and nannofossil oozes, with only a minor volcanic portion) and there contributed to the formation of zeolites (mostly clinoptilolite, as reported by the shipboard party), which are abundant in the upper $590 \mathrm{~m}$.

Calcium is known to be readily released from sideromelane during low-temperature alteration such as palagonitization. Nevertheless, alteration of thick sections of basalt drilled by the Glomar Challenger is generally not severe enough to cause a decrease by more than about $20 \%$, especially when $\mathrm{Ca}$ is fixed in carbonate (e.g., Robinson et al., 1977). Clastic volcanogenic rocks instead generally show a drastic decrease in $\mathrm{Ca}$ (when it is not fixed in carbonate) during alteration (e.g., Simon and Schmincke, 1984), owing to the dominance of mostly vitric clasts and high reaction-surface ratios. The basaltic volcaniclastic sequence of Unit VI must have lost up to $50 \%$ of its calcium during early(?) diagenesis when the sideromelane was transformed into palagonite, as shown by comparison of electron microprobe analyses of palagonite with corresponding phenocryst compositions. 
Apparently, the $p \mathrm{CO}_{2}$ was not high enough to fix $\mathrm{Ca}$ in calcite, possibly because the content of organic matter, which would release $\mathrm{CO}_{2}$ upon decomposition, is low in rapidly accumulated volcaniclastic sediments. Calcite is a rare cement, and has crystallized rather late. We interpret the common occurrence of chabazite and sphene to indicate that some of the massive loss of calcium from the glass has been fixed in the system. This is also reflected in the whole-rock chemistry.

The occurrence of gyrolite in association with apophyllite, Ca-sulfate, and Ca-carbonate in Sample 585A$19-2,89-95 \mathrm{~cm}$, from the lower debris-flow sequence, indicates some abnormal hydrothermal conditions, which could well be due to an intrusion rather than to increasing temperature with depth.

\section{Conclusions}

Volcaniclastic rocks of Site 585 Unit VI, upper Aptian to middle Albian, are subdivided into a lower tholeiitic and an upper alkali basaltic sequence. The source of the clastic material of both sequences, which have been deposited by debris flows and turbidity currents, respectively, must be dominantly or entirely a shallow-water environment (perhaps less than about $300 \mathrm{~m}$ water depth), except for some subaerial, chiefly epiclastic, debris. This is indicated by (1) shallow-water calcareous clasts, (2) high vesicularity of pyroclasts in the upper sequence, (3) predepositional oxidation of some olivines, and (4) rounding of crystalline basalt clasts.

Shallow-water to emergent conditions would fit the model of a seamount-to-volcanic-island scenario. The drill site is located some $70 \mathrm{~km}$ north of Ita Maitai Guyot, whose top is presently under $1500 \mathrm{~m}$ of water (Fig. 1). On Leg 20, a Quaternary to Tertiary carbonate sequence, with some basaltic fragments (of the volcanic base) embedded in ooze, was drilled on top of the guyot (Heezen, MacGregor et al., 1973). We speculate that the volcaniclastics drilled at Site 585 were generated on Ita Maitai seamount during Aptian to Albian time by explosive volcanic activity and synvolcanic clastic processes such as spalling, granulation, or breakage during entrance of lavas into the sea. Volcanism on Ita Maitai was thus contemporaneous with the first of two major Cretaceous periods of extensive volcanic activity in the western Pacific-which resulted in a larger number of guyots, some of which were dredged during ARIES IV (Heezen et al., 1973) - as well as with the formation of several oceanic plateaus (Rea and Vallier, 1983). The synchrony is paralleled by the chemical similarity of the erupted enriched tholeiitic magmas (Stoeser, 1975; Scott, 1981). Interestingly, the change from enriched tholeiitic to alkali basalts resembles that characteristic of many oceanic islands, although we do not know if all volcaniclastic material drilled came from the same source. Nor can we specify the time it took to deposit the $300-\mathrm{m}$ thick sequence.

Diagenetic alteration of the studied dominantly vitric tuffs resulted in secondary mineral assemblages of mostly palagonite, chlorite/smectite mixed minerals, analcite, and chabazite. Relict structures indicate that phillipsite was replaced by analcite. Surprisingly, the sediments lack the K-enrichment typical of seafloor weathering. This may have been prevented by rapid sedimentation.

\section{ACKNOWLEDGMENTS}

We thank P. Floyd and G. Schäfer for sampling volcaniclastic rocks on board. Henni Niephaus as usual provided us with excellent chemical analyses, and G. Olesch skillfully prepared the thin sections. Thanks to the draftsmen H. Bauszus, R. Schumacher, and A. Freundt, and to the photographer A. Fischer. We appreciate the helpful comments on our manuscript offered by R. Batiza, M. J. F. Flower, R. V. Fisher, P. Floyd, and T. Vallier. This study had been financed by the Deutsche Forschungsgemeinschaft (Grants Schm 250-9/10).

\section{REFERENCES}

Andrews, A. J., 1980. Saponite and celadonite in Layer 2 basalts, DSDP Leg 37. Contrib. Mineral. Petrol., 73:323-340.

Bass, M. N., Moberly R., Rhodes, J. M., Skih, C., and Church, S. E., 1973. Volcanic rocks cored in the central Pacific, Leg 17, Deep Sea Drilling Project. In Winterer, E. L., Ewing, J. I., et al., Init. Repts. DSDP, 17: Washington (U.S. Govt. Printing Office), 479503.

Deer, W. A., Howie, R. A., and Zussman, J., 1964a. Rock-forming Minerals (Vol. 3: Sheet Silicates): London (Longmans).

,1964b. Rock-forming Minerals (Vol. 4: Framework Silicates): London (Longmans).

Evans B. W., and Moore, J. G., 1968. Mineralogy as a function of depth in the prehistoric Makaopuhi tholeiitic lava lake, Hawaii. Contrib. Mineral. Petrol., 17:85-115.

Evans, B. W., and Wright, T. L., 1972. Composition of liquidus chromite from the 1959 (Kilauea Iki) and 1965 (Makaopuhi) eruptions of Kilauea Volcano, Hawaii. Am. Mineral., 57:217-230.

Fisher, R. V., and Schmincke, H. U., 1984. Pyroclastic Rocks: Berlin and Heidelberg (Springer Verlag).

Fodor, R. V., Keil, K., and Bunch, T. E., 1975. Contributions to the mineral chemistry of Hawaiian rocks IV. Pyroxenes in rocks from Haleakala and West Maui volcanoes, Maui, Hawaii. Contrib. Mineral. Petrol., 50:173-195.

Foster, M. D., 1969. Studies of celadonite and glauconite. Prof. Pap. U.S. Geol. Surv., 614F.

Frey, F. A., Clague, D. A., 1983. Geochemistry of diverse basalt types from Loihi Seamount, Hawaii: Petrogenetic implications. Earth Planet. Sci. Lett., 66:337-355.

Gude, A. J., 3rd, and Shepperd, R. A., 1966. Silica-rich chabazite from the Barstow Formation, San Bernardino County, southern California. Am. Mineral., 57:909-915.

Heezen, B. C., MacGregor, I. D., et al., 1973. Tertiary pelagic ooze on Ita Maitai Guyot, Equatorial Pacific: DSDP Sites 200 and 201. In Heezen, B. C., MacGregor, I. D., et al., Init. Repts. DSDP, 20: Washington (U.S. Govt. Printing Office), 87-102.

Heezen, B. C., Matthews, J. L., Catalano, R., Natland, J., Coogan, A., et al., 1973. Western Pacific guyots. In Heezen, B. C., MacGregor, I. D., et al., Init. Repts. DSDP, 20: Washington (U.S. Govt. Printing Office), 653-723.

Honnorez, J., 1981. The aging of the oceanic crust at low temperature. In Emiliani, C. (Ed.), The Sea (Vol. 7): The Ocean Lithosphere): London (Academic press), 525-587.

Iijima, A., and Harada, K., 1968. Authigenic zeolites in zeolitic palagonite tuffs on Oahu, Hawaii. Am. Mineral., 54:182-197.

Jackson, E. D., Bargar, K, E., Fabbi, B. P., and Heropoulos, C., 1976. Petrology of the basaltic rocks drilled on Leg 33 of the Deep Sea Drilling Project. In Schlanger, S. O., Jackson, E. D., et al., Init. Repts. DSDP, 33: Washington (U.S. Govt. Printing Office), 571-630.

Kastner, M., 1981. Authigenic silicates in deep sea sediments: Formation and diagenesis. In Emiliani, C. (Ed.), The Sea (Vol. 7): The Oceanic Lithosphere): London (Academic Press), 915-980.

Passaglia E., 1970. The crystal chemistry of chabazites. Am. Mineral., 55:1278-1301.

Pearce, J. A., 1982. Trace element characteristics of lavas from destructive plate boundaries. In Thorpe, R. S. (Ed.), Andesites: New York (John Wiley and Sons), pp. 526-548.

Rea, D. K., and Vallier, T. L., 1983. Two Cretaceous volcanic episodes in the western Pacific Ocean. Geol. Soc. Am. Bull., 94:1430-1437. 
Robinson, P. T., Flower, M. F, J., Schmincke, H.-U., and Ohnmacht, W., 1977. Low temperature alteration of oceanic basalts, DSDP Leg 37. In Aumento, F., Melson, W. G., et al., Init. Repts. DSDP, 37: Washington (U.S. Govt. Printing Office), 775-793.

Sachtleben, T., Schmincke. H.-U., Hertogen, J., and Jenner, G. A., in press. Petrology and geochemistry of Leg 82 basalts. In Bougault. H., Cande, S. C., et al., Init. Repts. DSDP, 82: Washington (U.S. Govt. Printing Office).

Schmincke, H.-U., 1983. Ash layers, hyaloclastite, and alteration of basaltic glass, Leg 65. In Lewis, B. T. R., Robinson, P., et al., Init. Repts. DSDP, 65: Washington (U.S. Govt. Printing Office), 789831.

Schmincke, H.-U., Viereck, L. G., Griffin, B. J., and Pritchard, R. G., 1982. Volcaniclastic rocks of the Reydarfjordur drill hole, eastern Iceland. 1. Primary features. J. Geophys. Res., 87:6437-6458.

Schweitzer, E. L., Papike, J. J., and Bence, A. E., 1979. Statistical analysis of clinopyroxenes from deep-sea basalts. Am. Mineral., 64:501-513.

Scott, R. B., 1981. Geochemistry of igneous rocks in Deep Sea Drilling Project Hole 465A, Hess Rise: Significance to oceanic plateau petrology and evolution. In Thiede, J., Vallier, T. L., et al., Init. Repts. DSDP, 62: Washington (U.S. Govt. Printing Office), 955960.

Shcheka, S., 1981. Igneous rocks of Deep Sea Drilling Project Leg 61, Nauru Basin. In Larson, R. L., Schlanger, S. O., et al., Init. Repts. $D S D P, 61$ : Washington (U.S. Govt. Printing Office), 633-646.

Sigurdsson. H., and Schilling, J.-G., 1976. Spinels in Mid-Atlantic Ridge basalts: Chemistry and occurrence. Earth Planet. Sci. Lett., 29:7-20.
Simon, M., and Schmincke, H.-U., 1984. Late Cretaceous volcaniclastic rocks from the Walvis Ridge, southeast Atlantic, Leg 74. In Moore, T. C., Jr., Rabinowitz, P. D., et al., Init. Repts. DSDP, 74: Washington (U.S. Govt. Printing Office), 765-791.

Speakman, K., 1968. The stability of tobermorite in the system CaO$\mathrm{SiO}_{2}-\mathrm{H}_{2} \mathrm{O}$ at elevated temperatures and pressures. Mineral. Mag., 36:1090-1103.

Staudigel, H., and Hart, S. R., 1983. Alteration of basaltic glass: Mechanisms and significance for the oceanic crust-seawater budget. Geochim. Coschim. Acta, 47:337-350.

Stoeser, D. B., 1975. Igneous rocks from Leg 30 of the Deep Sea Drilling Project. In Andrews, J. E., Packham, G., et al., Init. Repts. $D S D P, 30$ : Washington (U.S. Govt. Printing Office), 401-444.

Sukheswala, R. N., Avasia, R. K., and Gangopadhyay, M., 1974. Zeolites and associated minerals in the Deccan Traps of western India. Mineral. Mag., 39:658-671.

Vaughan, D. E. W., 1978. Properties of natural zeolites. In Sand, L. B., and Mumpton. A. (Eds.), Natural Zeolites. Occurrence, Properties, Use: Oxford (Pergamon), pp. 353-371.

Viereck, L. G., Griffin, B. J., Schmincke, H.-U., and Pritchard, R. G., 1982. Volcaniclastic rocks of the Reydarfjordur drill hole eastern Iceland. 2. Alteration. J. Geophys. Res., 87(B8):6459-6476.

Wood, D. A., Varet, J., Bougault, H., Corre, O., Joron, J. L., et al., 1979. The petrology, geochemistry, and mineralogy of North Atlantic basalts: A discussion based on IPOD Leg 49. In Luyendyk, B. P., Cann, J. R., et al., Init. Repts. DSDP, 49: Washington (U.S. Govt. Printing Office), 597-655.

Date of Initial Receipt: 9 July 1984

Date of Acceptance: 7 September 1984 


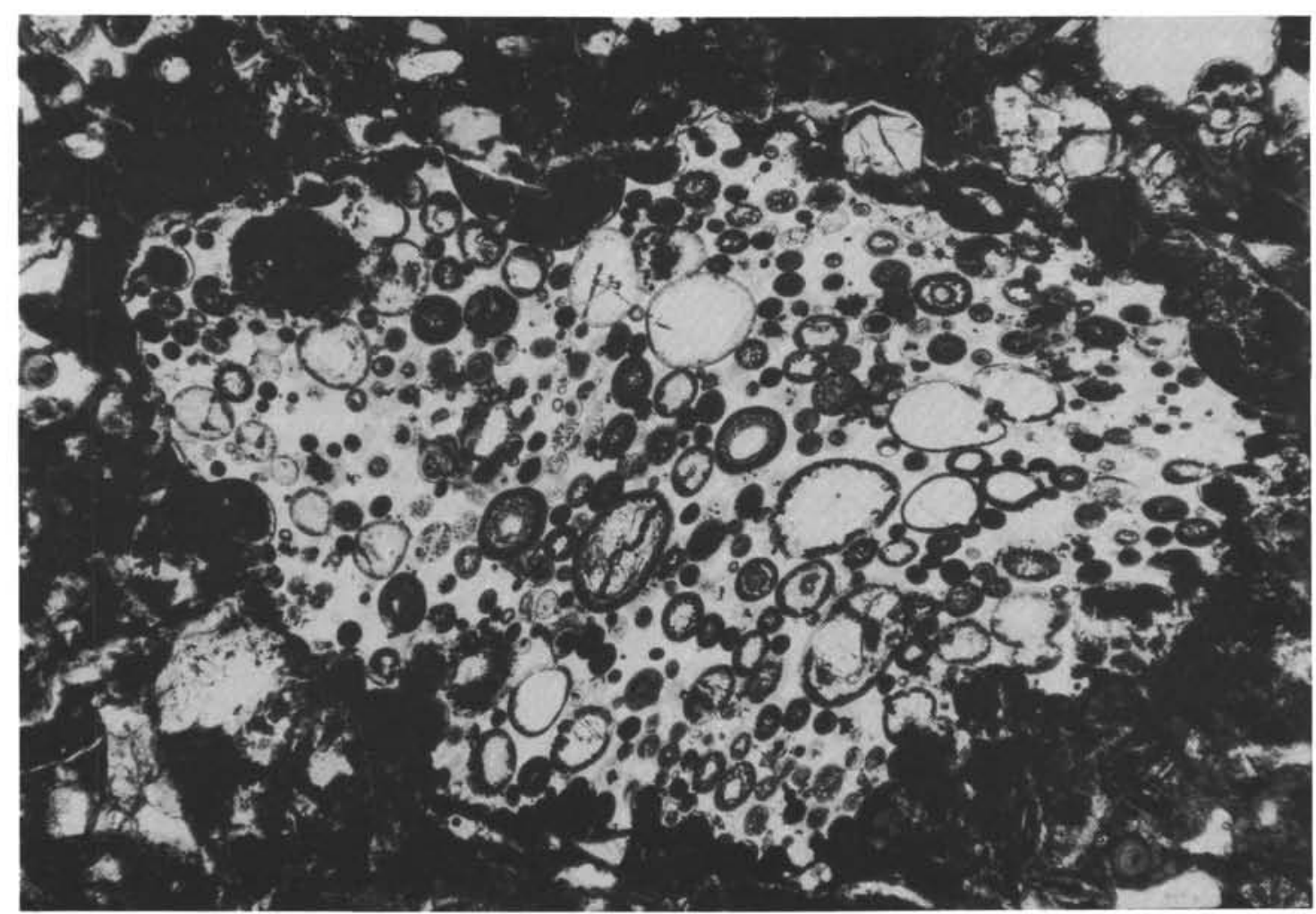

1.

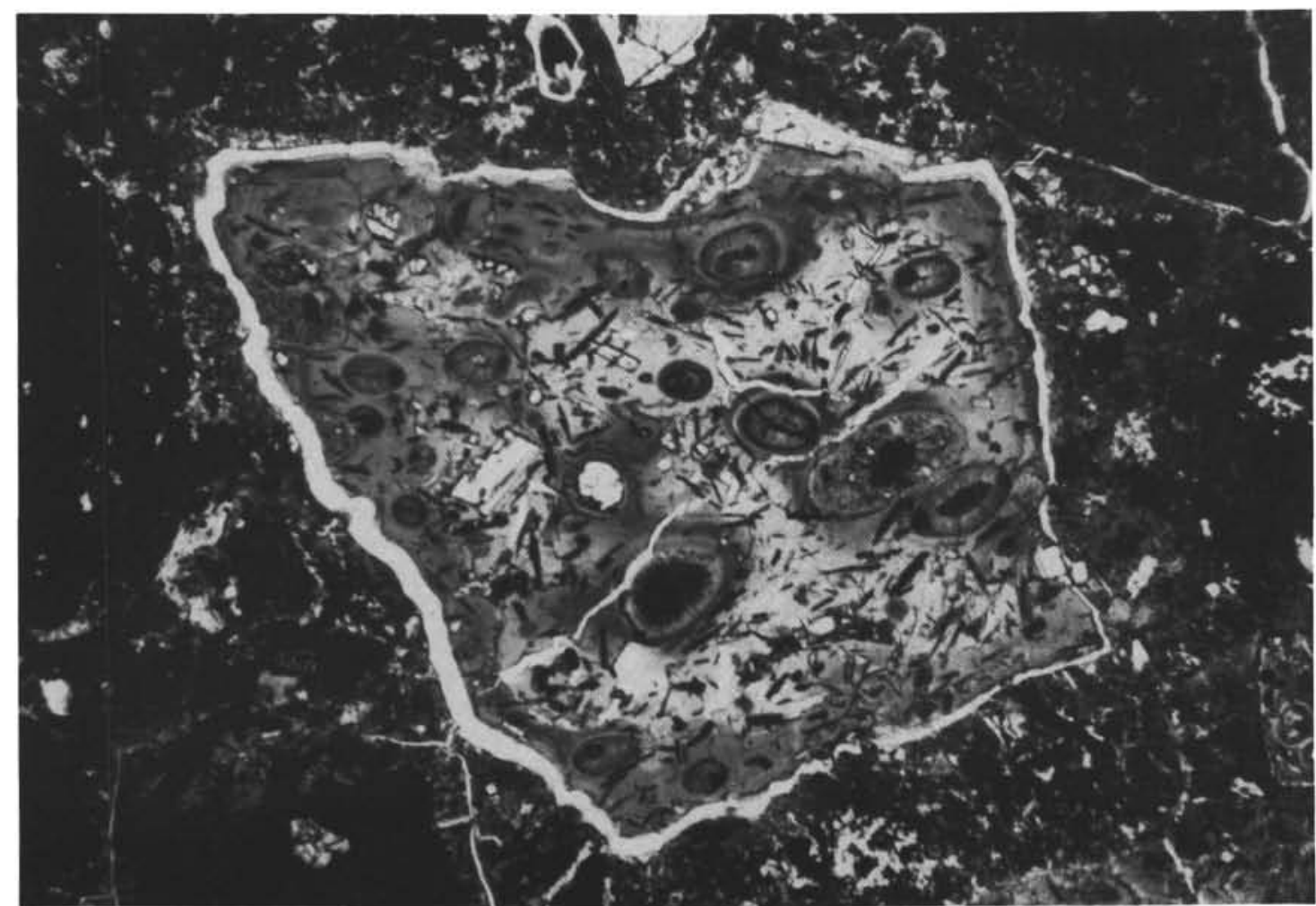

2.

Plate 1. Types of shards. 1. Vesicular scoria shard completely replaced by analcite in Sample 585-48-1, $142-146 \mathrm{~cm}$. Note filling of small vesicles and lining of large vesicles by chlorite/smectite mixed minerals. (Length of photo $=0.6 \mathrm{~mm}$ ). 2. Blocky palagonitized shard in Sample 585-48-1, $32-36 \mathrm{~cm}$, showing prismatic microphenocrysts of pyroxene; dark laths are plagioclase replaced by chlorite/smectite mixed minerals. Shrinkage cracks are due to dehydration. (Length of photo $=2.2 \mathrm{~mm}$ ). 


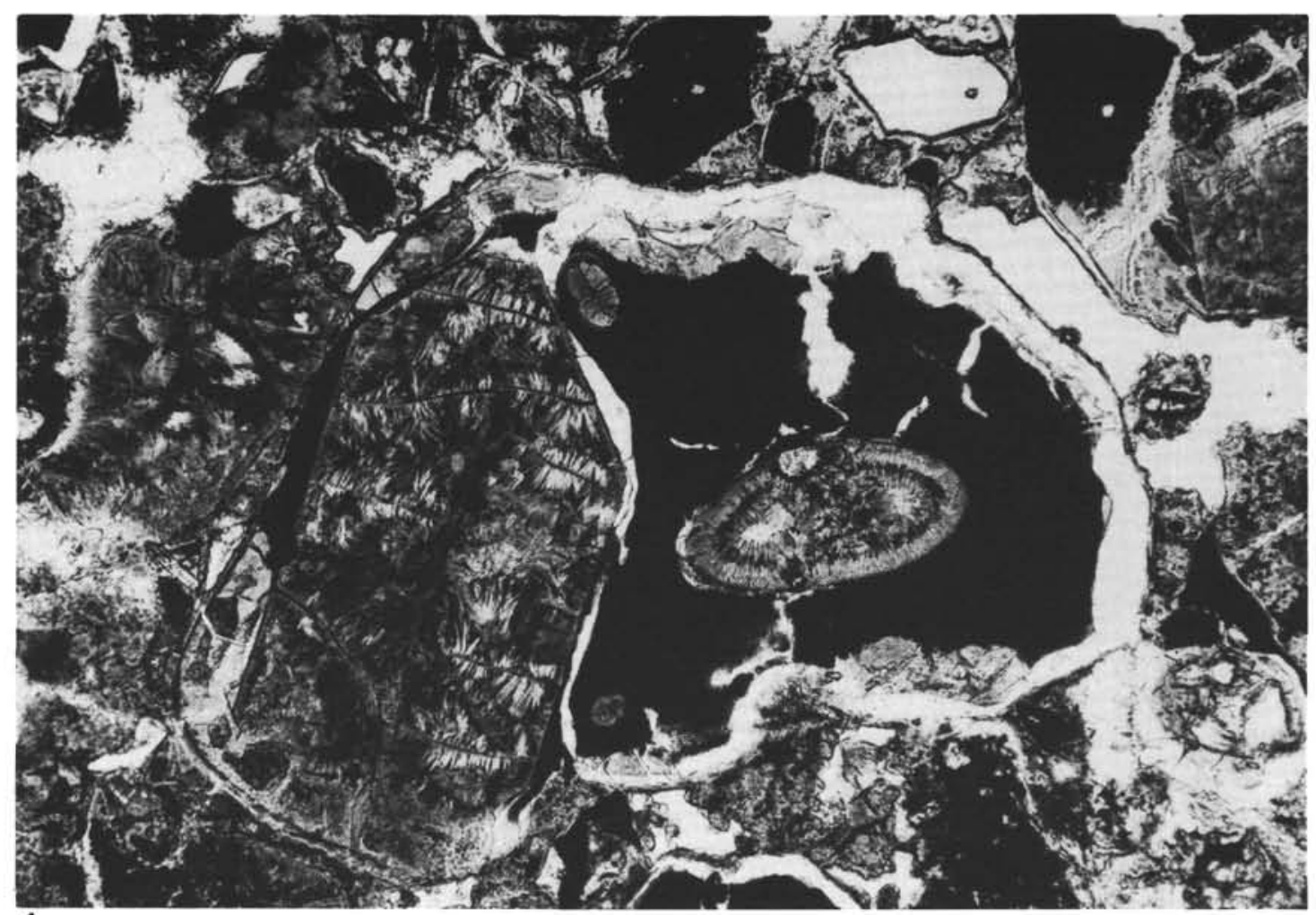

1.

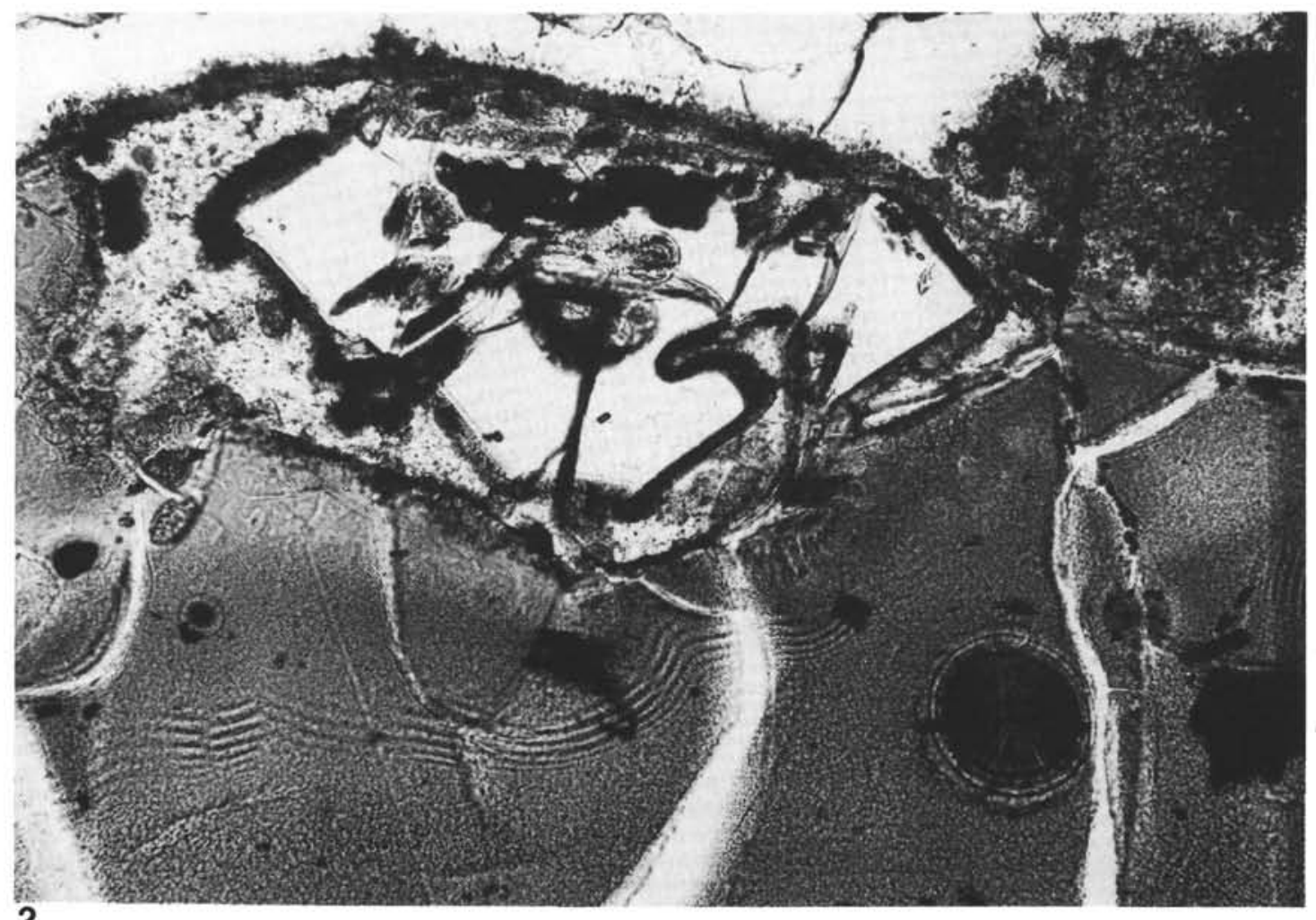

2.

Plate 2. Replacement of olivine. 1. Isomorphic replacement of subhedral olivine phenocryst by aggregates of chlorite/smectite mixed minerals in strongly oxidized palagonitic shard (note shrinkage cracks). Vesicles are also filled by chlorite/smectite mixed minerals. (Sample 585-55-3, 122$127 \mathrm{~cm}$; length of photo $=0.6 \mathrm{~mm}$.) 2. Isomorphic replacement of subhedral olivine phenocryst by clear analcite in banded palagonitic shard. Note aureole of "dusty" analcite around olivine. (Sample 585A-19-2, 89-95 cm; length of photo $=0.1 \mathrm{~mm}$.) 


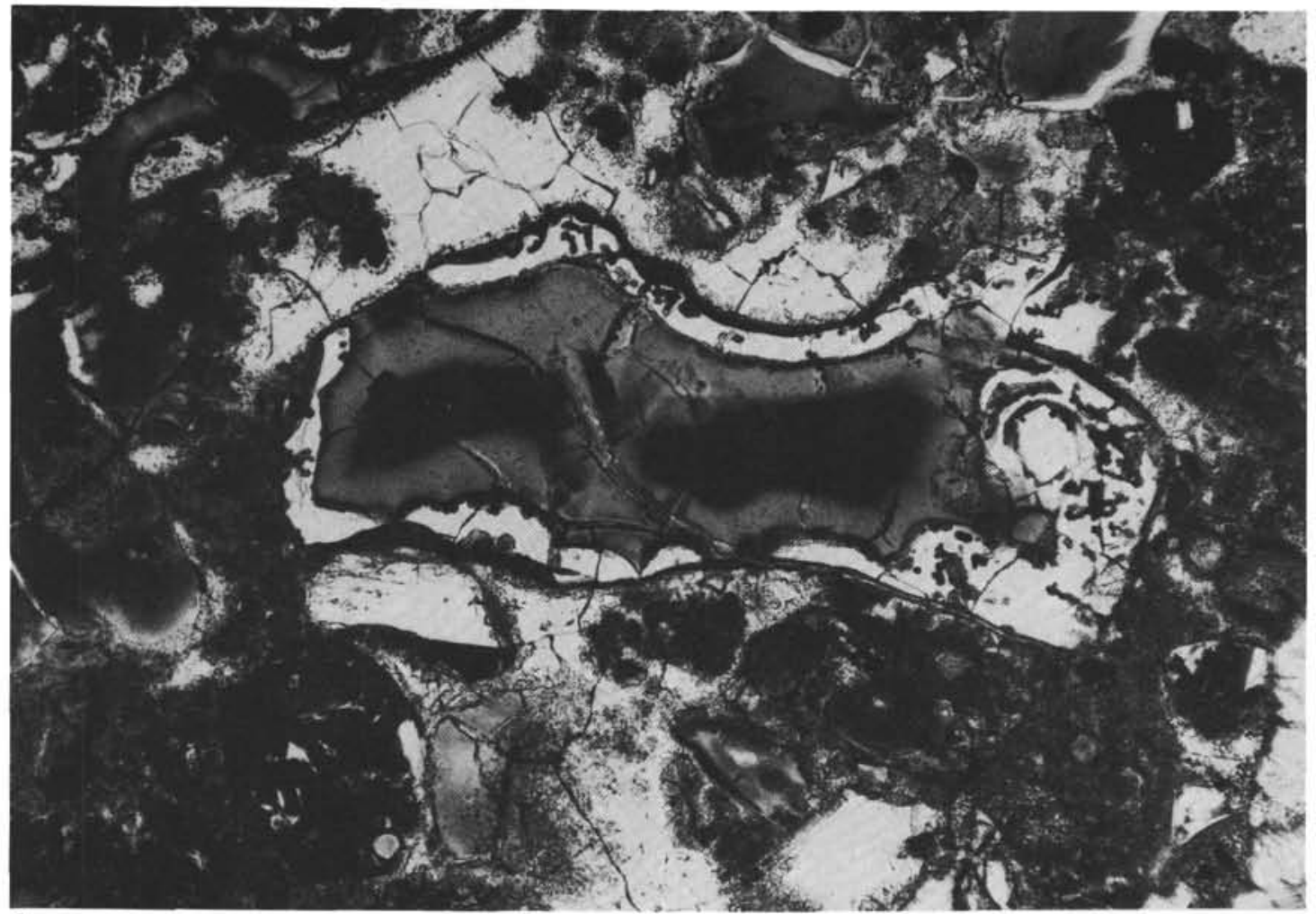

1.

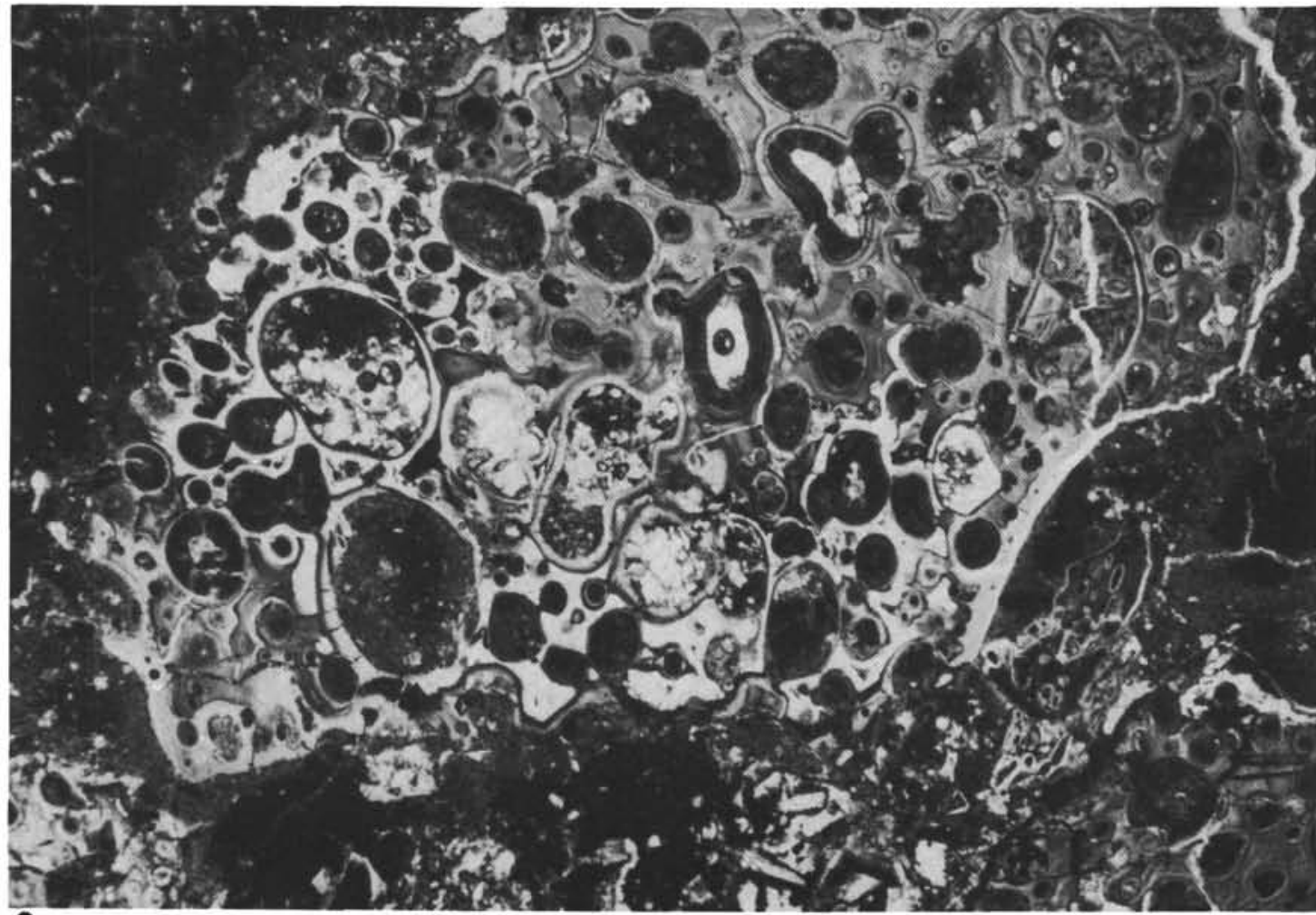

2

Plate 3. Alteration of shards. 1. Vesicle-free shard with Fe-Ti-enriched dark core, palagonitic mantle, and colorless zeolitic rim (analcite) with isolated spheres of leucoxene. Primary pores above shard are filled with chabazite. (Sample 585A-19-2, 89-95 cm; length of photo $=0.6 \mathrm{~mm}$.). 2. Palagonitic scoria shard, partly replaced by analcite (white area in left part of shard) and isolated concave-shaped ridges of leucoxene (arrows). Vesicles are filled or lined by chlorite/smectite mixed minerals and chabazite (Sample 585-48-1, 32-36 cm; length of photo $=2.2 \mathrm{~mm}$.). 


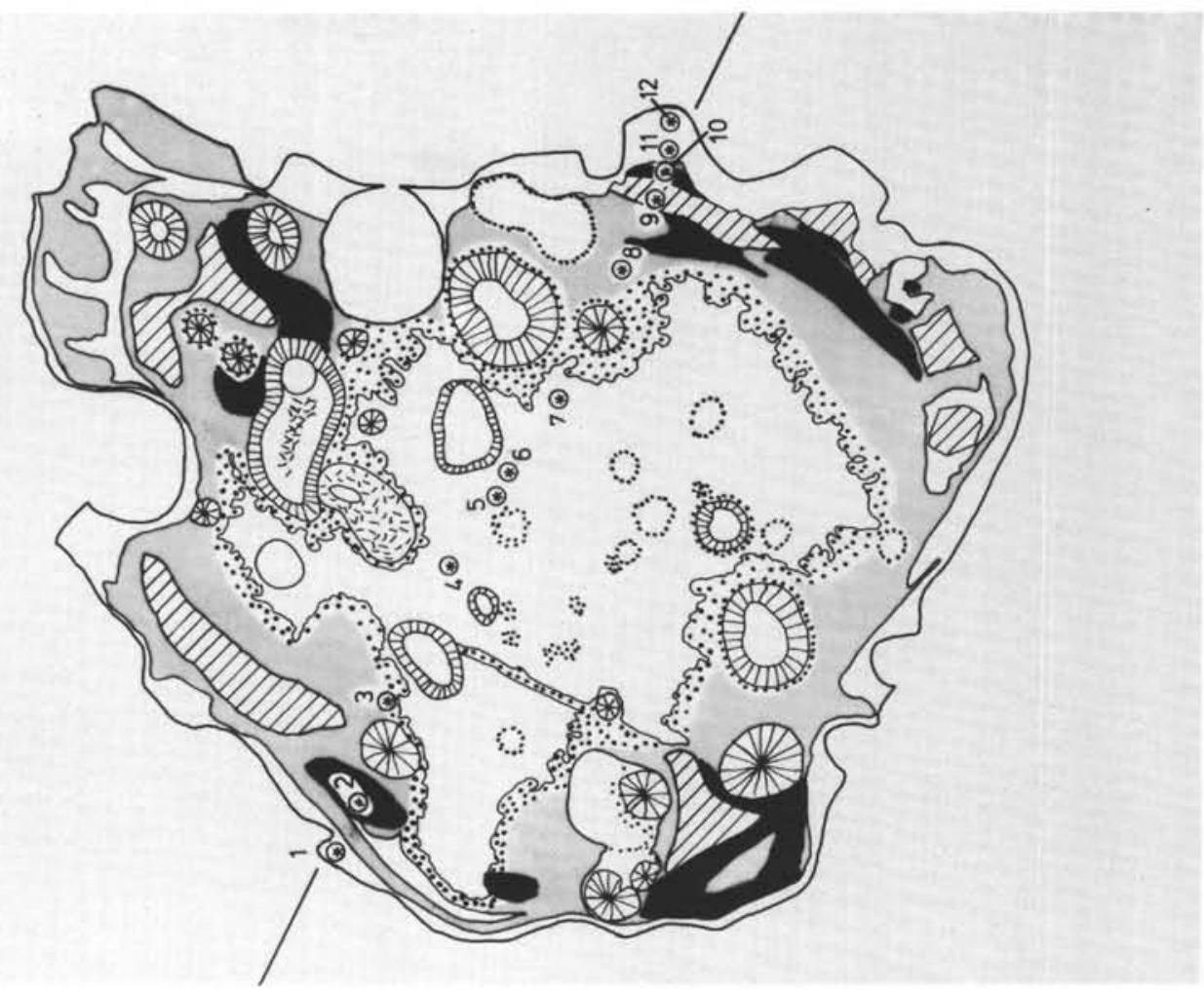

1.

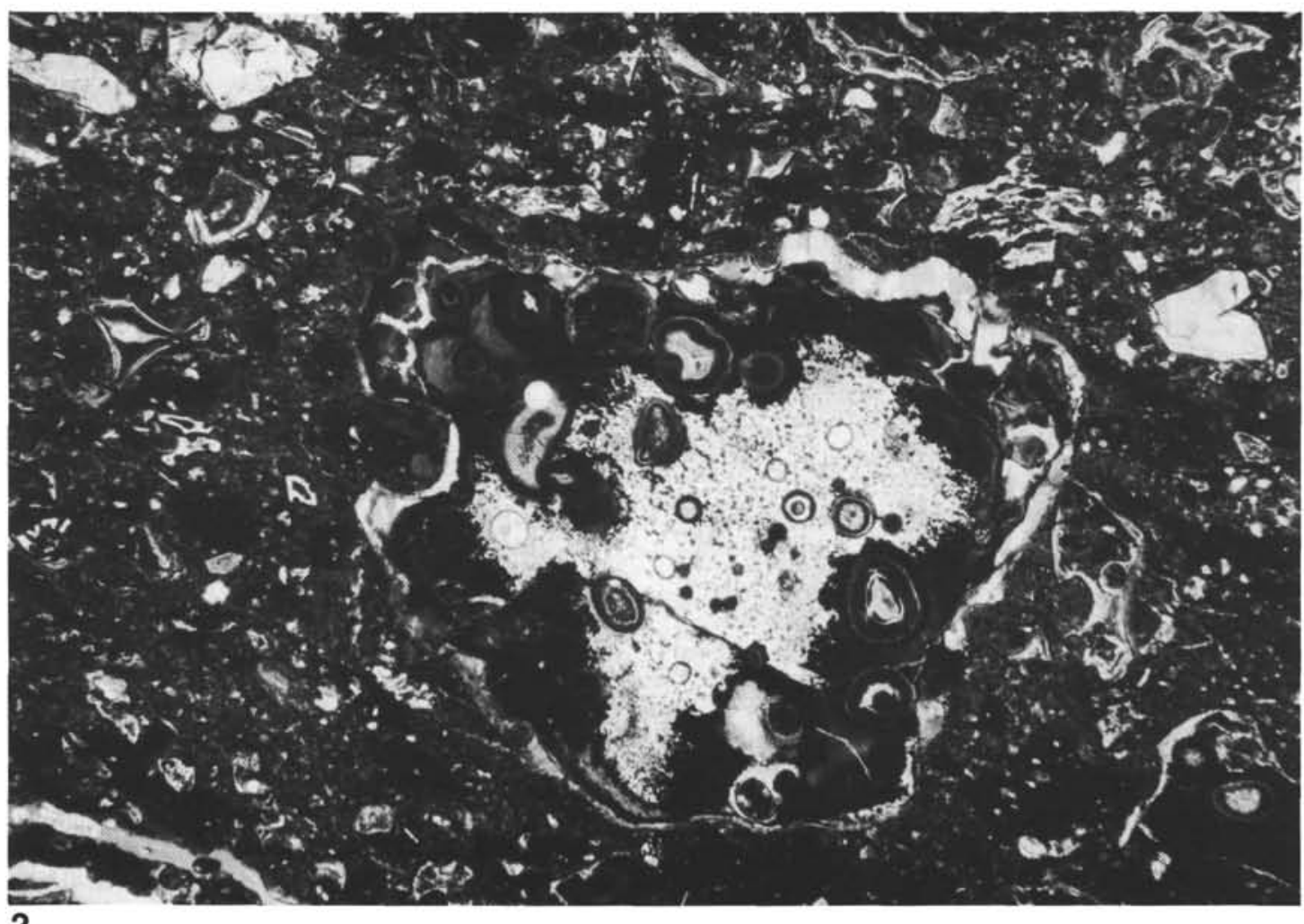

Plate 4. Alteration of shards. 1-2. Sketch and microphotograph of shard in Sample 585-49-2, 108-110 cm (cf. Table 8, Fig. 10). Note analcite rim, $\mathrm{Fe}-\mathrm{Ti}-\mathrm{Mg}$-enriched, opaque to dark brown mantle zone, and chabazite core with abundant spherical leucoxene aggregates, partly lining contours of former vesicles. (Length of photo $=2.2 \mathrm{~mm}$.) 


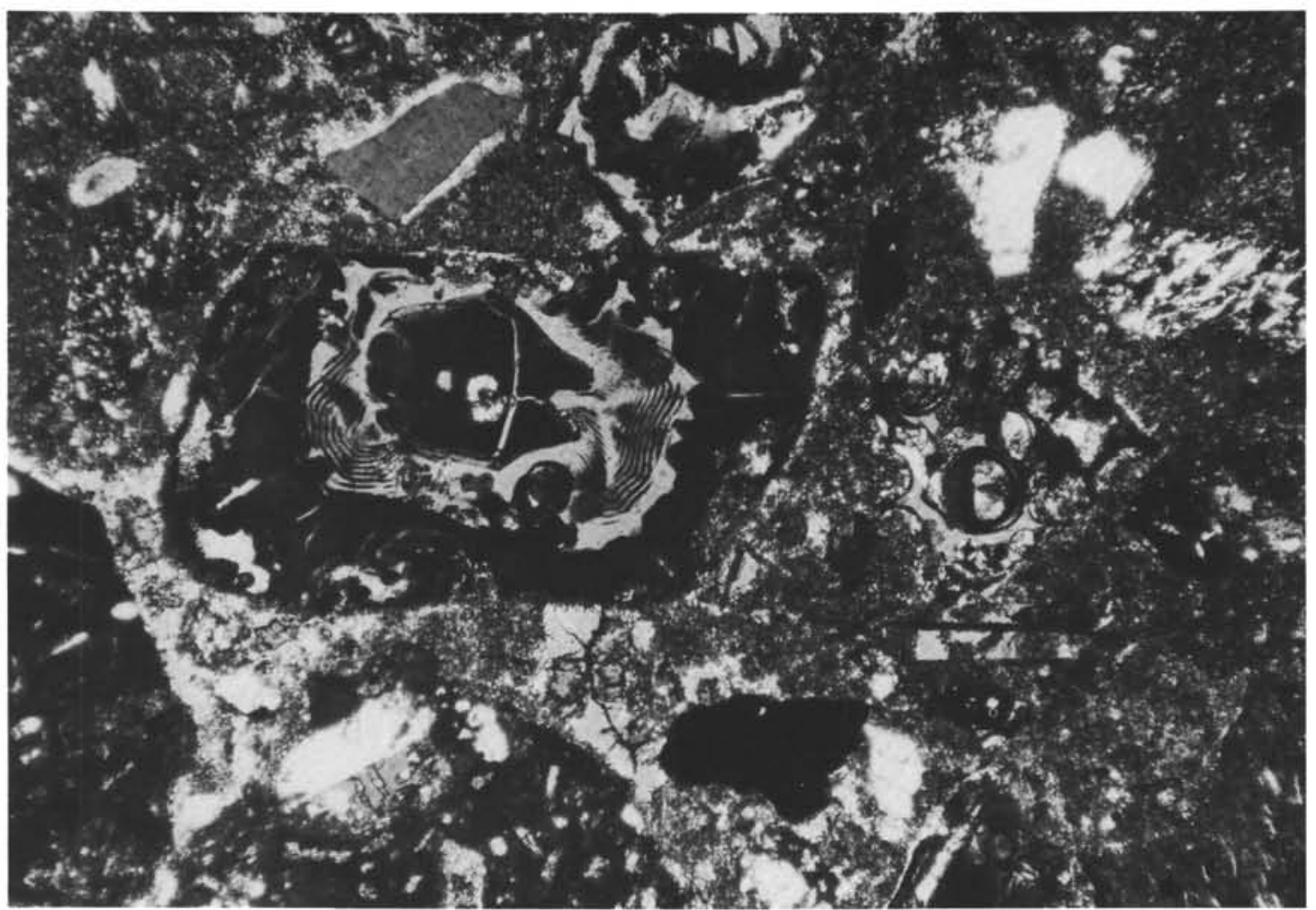

1.

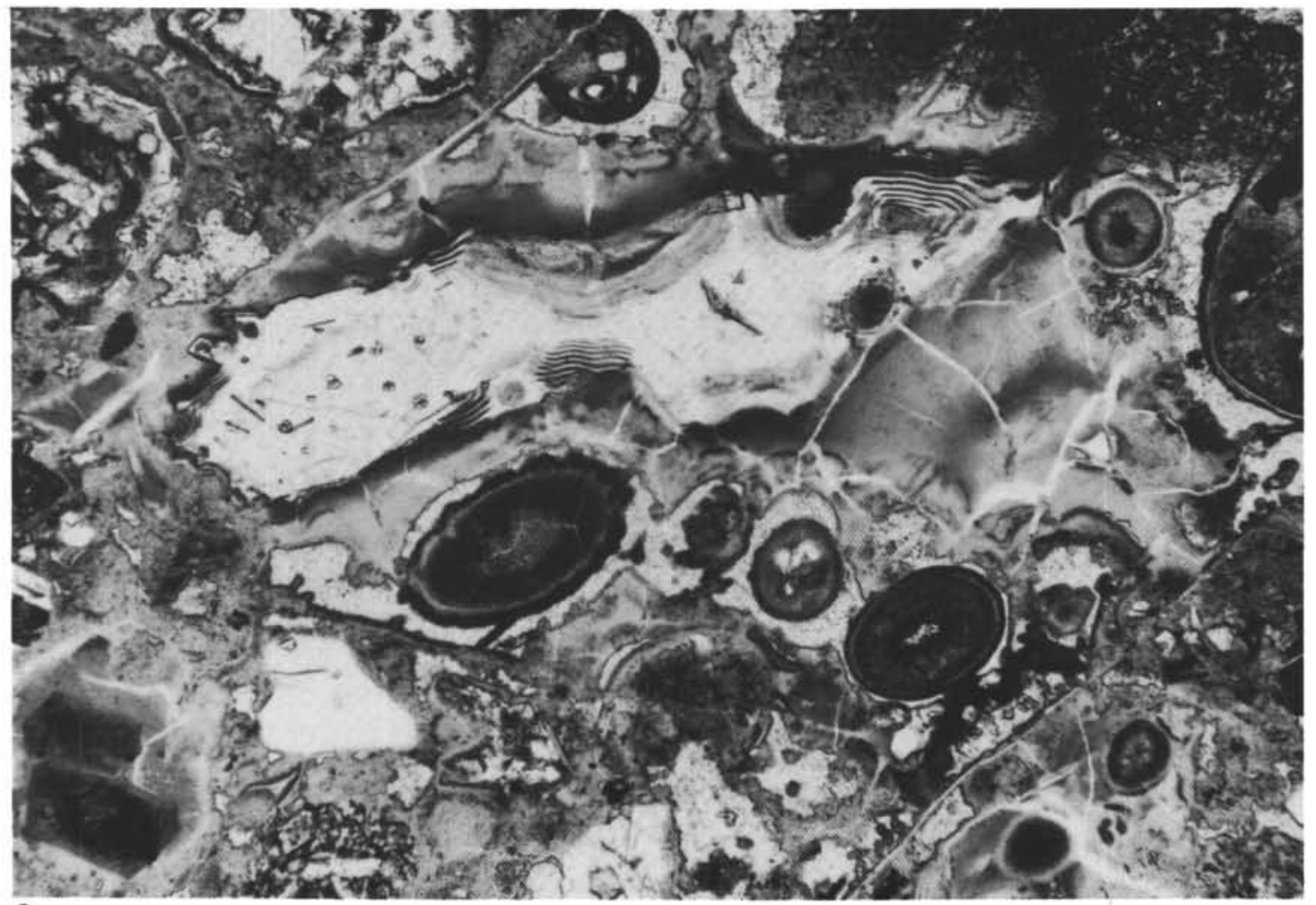

2.

Plate 5. Alteration of shards. 1. Equally spaced concentric zones of Fe-Ti enrichment in zeolitized (analcite) mantle of shard with opaque to red brown Fe-Ti-Mg-enriched core and outer mantle. (Sample 585A-19-1, 42-45 cm; length of photo $=2.2 \mathrm{~mm}$.) 2. Zeolitized field (white, analcite) in palagonitic shard (shades of gray) with well-preserved subparallel banding, vesicles filled with chlorite/smectite mixed minerals. Note additional zeolitization of shard (dusty white areas, analcite replacing phillipsite) starting from the outer contours and vesicles. (Samples 585-18-6, $90-92 \mathrm{~cm}$; length of photo $=0.6 \mathrm{~mm}$ ) 